\title{
Foraging Activity in Plebeia remota, a Stingless Bees Species, Is Influenced by the Reproductive State of a Colony
}

\author{
Patrícia Nunes-Silva, ${ }^{1}$ Sergio Dias Hilário, ${ }^{2}$ Pérsio de Souza Santos Filho, ${ }^{3}$ \\ and Vera Lucia Imperatriz-Fonseca ${ }^{3}$ \\ ${ }^{1}$ Departament of Biology, Faculty of Philosophy, Science and Letters of Ribeirão Preto, University of Sao Paulo, \\ Ribeirão Preto 14040-030, Brazil \\ ${ }^{2}$ Departament of Zoology, Institute of Bioscience, University of Sao Paulo, Sao Paulo 05508-900, Brazil \\ ${ }^{3}$ Departament of Ecology, Institute of Bioscience, University of Sao Paulo, Sao Paulo 05508-900, Brazil \\ Correspondence should be addressed to Patrícia Nunes-Silva, pnsilva@usp.br \\ Received 30 July 2009; Accepted 12 March 2010 \\ Academic Editor: Koos (J.C.) Biesmeijer
}

Copyright () 2010 Patrícia Nunes-Silva et al. This is an open access article distributed under the Creative Commons Attribution License, which permits unrestricted use, distribution, and reproduction in any medium, provided the original work is properly cited.

Colonies of the Brazilian stingless bee Plebeia remota show a reproductive diapause in autumn and winter. Therefore, they present two distinct reproductive states, during which colony needs are putatively different. Consequently, foraging should be adapted to the different needs. We recorded the foraging activity of two colonies for 30 days in both phases. Indeed, it presented different patterns during the two phases. In the reproductive diapause, the resource predominantly collected by the foragers was nectar. The majority of the bees were nectar foragers, and the peak of collecting activity occurred around noon. Instead, in the reproductive phase, the predominantly collected resource was pollen, and the peak of activity occurred around 10:00 am. Although the majority of the foragers were not specialized in this phase, there were a larger number of pollen foragers compared to the phase of reproductive diapause. The temperature and relative humidity also influenced the foraging activity.

\section{Introduction}

Stingless bees collect several types of material on their foraging flights. Most of these materials have vegetal origin, as pollen, nectar, resin, latex, leaves, trichomes, fragrances, oils, seeds, and so forth. In addition, stingless bees also collect materials of other origins, as animal feces, clay, water, and fungi spores, for example [1-3].

Among all these resources, pollen, and nectar are the ones used as food [4]. In some bee species oil is also used to provision brood cells, as in Centris (Hemisiella) tarsata [5] and $C$. (H.) trigonoides [6]. The other materials can be used for several purposes, especially construction and protection $[2,4]$. The flight activity includes waste removal, namely, to remove garbage (detritus) from the colony, besides foraging. The detritus comprise feces, old combs, dead bees, larval and pupal exuvia, among others $[1,2,7]$.

The foraging behavior varies seasonally throughout the year, especially in relation to the amount of pollen collected by the colonies. Climatic factors such as temperature, light intensity, wind, rain, and relative humidity, as well as plant resource availability, influence foraging. Colony internal factors, such as population size and amount of stored food, also influence the foraging behavior of the individual bees and of the colony $[2,4,8-12]$.

Several aspects of the flight and foraging activity of some stingless bee species have already been studied: (i) the influence of external and internal factors, (ii) the size and the physiology of the bees, and (iii) the effect of daily and seasonal patterns of availability of floral resources on foraging. However, among the species that present reproductive diapause, the foraging pattern and the flight activity in relation to the phase of diapause and the phase of oviposition by the queen were studied comparatively only in Plebeia saiqui $[13,14]$.

Reproductive diapause is characterized by an interruption in cell provisioning and oviposition process (POP) in autumn and winter [15-17]. In stingless bees the provisioning and oviposition process (POP) comprises (i) the construction of brood cells one by one, (ii) provisioning 
of them by the workers, (iii) the oviposition by the queen, and (iv) sealing of the cells by the workers, then new cells are started [1]. Diapause also occurs in other stingless bee species, especially in the genus Plebeia: $P$. remota $[15,17], P$. droryana [18], P. julianii [19], and P. wittmanni [20] and has also been observed in some colonies of Melipona marginata obscurior [21]. In this phase many changes in the architecture (i.e., construction of storage pots on the top of the pile of old combs) of the nest and in the behavior of the queens and workers occur, at least in P. remota [17]. In this species even the defensive behavior of the bees is modified during the reproductive diapause [22].

Hilário et al. [23-25] studied the influence of climatic factors on the flight activity of $P$. remota, but he did not present observations on the influence of diapause in the foraging and waste removal behavior for this species. The main aim of this study was to test whether the foraging behavior of this species varies according to the reproductive state of the colony. More specifically we examined whether there are differences on the type and amount of resource collected by the bees in the different phases of reproduction and in the removal of detritus. The influence of the temperature and the relative humidity on this activity and the daily rhythm of the foraging of the colonies and individual foragers were also investigated, as the individual activities of the foragers.

\section{Material and Methods}

The study was carried out in the Bee Laboratory (Bioscience Institute, University of São Paulo; $23^{\circ} 33^{\prime} \mathrm{S}, 46^{\circ} 43^{\prime} \mathrm{W}$ ) in two periods: from May 8th to July 7th 2006 (reproductive diapause of colonies) and from November 13th 2006 to January 24th 2007 (reproductive phase).

We used two colonies of $P$. remota from Cunha $\left(23^{\circ} 05^{\prime} \mathrm{S}\right.$, $44^{\circ} 55^{\prime} \mathrm{O}$, São Paulo State). These colonies were hived in wooden boxes covered with glass lids and connected to the exterior of the laboratory by a plastic tube. Outside the building the tube was $15 \mathrm{~cm}$ long, so as to allow better observation of the activity of individual bees. Four hundred newly emerged bees were individually marked in each colony using a color code made with paint. This color code is based on five colors, each color representing a number, and on the position of the dot on the thorax (Figure 1). Dots in the center of the thorax mean 100 (white) to 500 (green). This system allows the researcher to mark 599 bees individually by combining the dots. For example, bee number 456 is marked with a blue dot on the center of the thorax, a green dot on the inner left side of the thorax, and a white dot on the upper right side. This is a marking system modified from Sakagami's system [26].

The observations were made between 8:00 and 18:00 (local time), for 20 minutes per hour in each colony, for 30 days distributed throughout each phase (a minimum of 3 times a week and maximum of 5 times a week). In these observations we counted the number of bees entering the colony and the number of bees taking out garbage, and registered the type of material carried by them (nectar, pollen, or resin). We also recorded the time and what

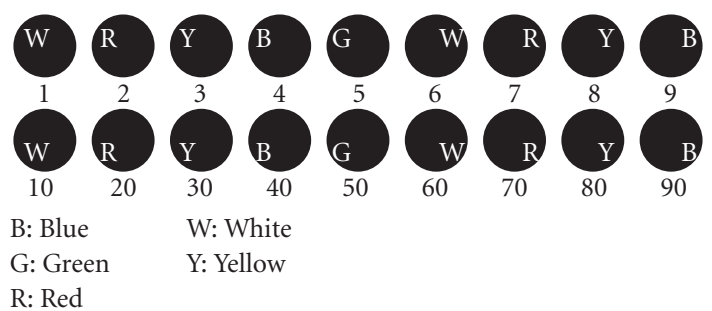

FIGURE 1: Marking system based on the position of the dots made with paint on the thorax of the bee. The black balls represent the thorax of the bee and the letters where the dots are made and the color of the paint.

resource individually marked bees foraged for. It was not possible to distinguish among bees bringing nectar, water, or nothing. Bees entering the hive without pollen or resin on the corbiculae were considered to bring nectar. To avoid an over estimation of bees collecting nectar, the number of bees removing garbage was subtracted from the number of bees collecting nectar, since these bees do not collect resources and come back rapidly without resources on the corbiculae, and they had been previously counted as bees collecting nectar.

We calculated the mean and standard deviations of the numbers of bees collecting nectar, pollen, and resin and removing garbage per hour, as well as the minimum and maximum numbers registered per colony. Since the datasets did not follow a normal distribution (Shapiro-Wilk test, $P<$ .05 ), we used Mann-Whitney test to compare two groups of data and Kruskall-Wallis test or Wilcoxon signed-rank test to compare more than two groups [27].

We calculated the partial correlation indexes between air temperature $\left({ }^{\circ} \mathrm{C}\right)$ and relative humidity (\%) and between these two environmental factors and nectar, pollen, and resin collection, total number of incoming trips in the colony and garbage removal. The controlled factors were the relative humidity and the air temperature. We also calculated Spearman correlation indexes between air temperature and relative humidity, and nectar, pollen, and resin collection and the total number of incoming trips in the colony. Weather data were provided by the Climatology and Biogeography Laboratory (Geography Department, Faculty of Philosophy, Letters, Science and History, University of São Paulo) from their experimental meteorological station at the University of São Paulo campus. The data were provided as means of five minutes of the temperature recordings. We used the mean of the four mean temperatures that corresponded to the 20 minutes of observation. To compare the air temperature and relative humidity between the two phases studied we used the Mann-Whitney test.

The analysis of the individual behavior of foragers was based on the activity performed (type of material collected or garbage removal) and on the frequency they performed it. We considered that bees that collected only one type of resource (nectar, pollen, and resin) in $80 \%$ or more of their flights were specialists in the collection of that resource, as Biesmeijer and Tóth [28] did. We also observed for how many days the marked bees foraged and their age. 


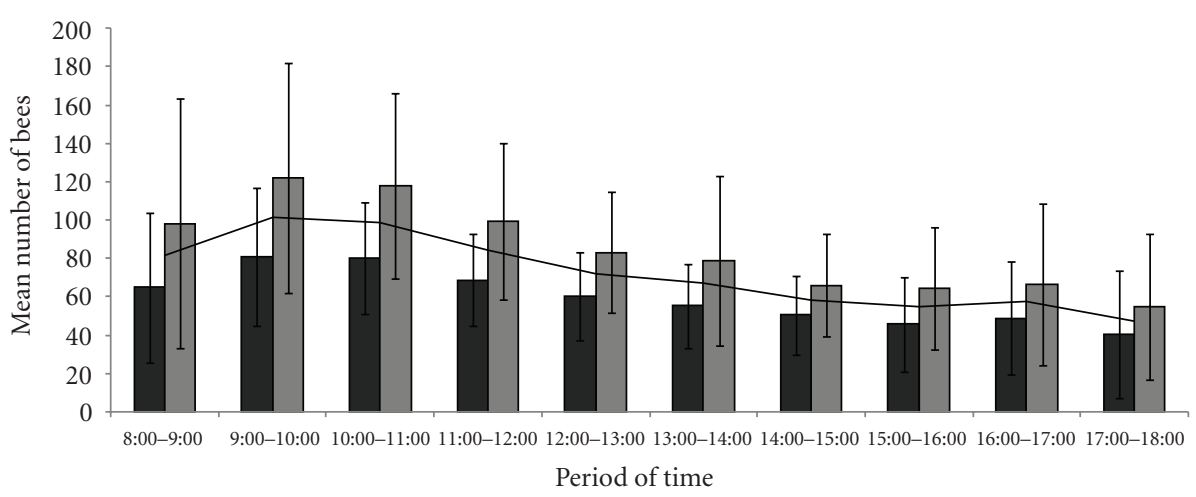

- Col 1

$\square \operatorname{Col} 2$

- Mean col 1/2

(a)

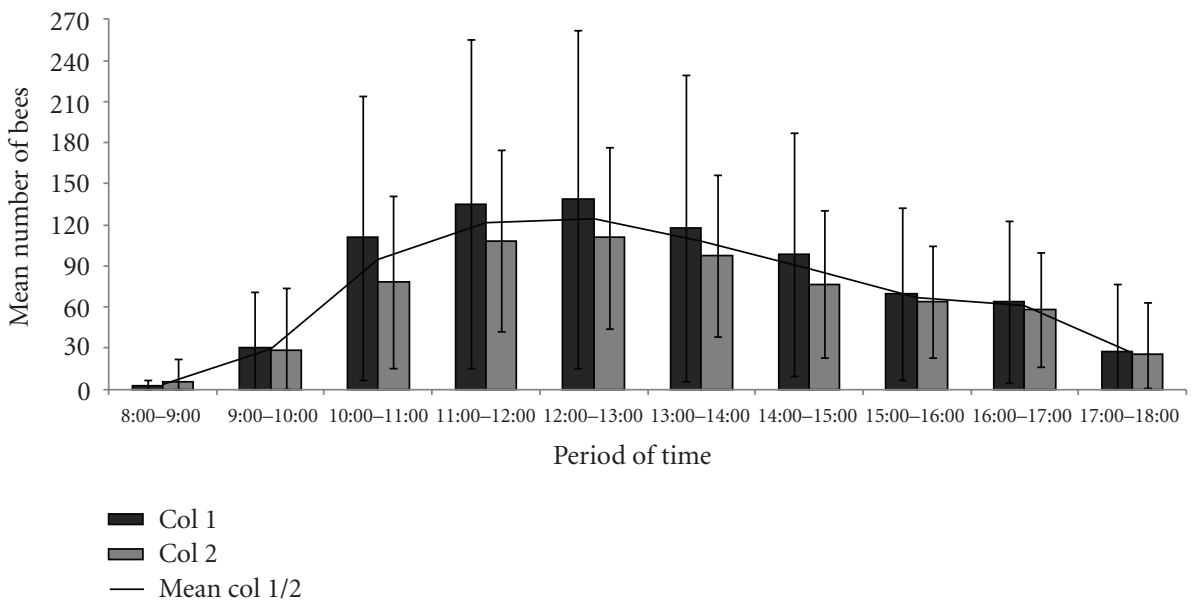

(b)

FIgURE 2: Total of entrances in two colonies of Plebeia remota in the reproductive phase (a) and in the diapause (b).

The foraging behavior of the colony and the individual foragers was also analyzed using rhythm tests. We tested whether the foraging of individual bees and of the colonies showed an acrophase (hr:min; local time) with the Rayleigh test $(P=.05)[27]$. We calculated the value of the acrophase of the colony and of individual marked bees (when the bee made six or more activities), the angular deviation of the acrophases and the mean vector $r$, which indicates the dispersion of the data around the acrophase; the greater the value of $r$, the less dispersion of the data around the acrophase [27].

\section{Results}

3.1. Foraging Patterns of Nectar, Pollen, Resin Collection, and Garbage Removal. There were differences in the foraging patterns between the reproductive and diapause phases. There was a statistically significant difference between the total number of bees collecting resources in the reproductive phase and during diapause (colonies 1 and 2, Mann-Whitney test, $P<.05)$.
In both colonies the total number of bees collecting resources in the reproductive phase increased until 9:00. A peak of activity was found between 9:00 and 11:00. After 11:00, the income of resources decreased until 13:00, remaining constant for the rest of the day (Figure 2(a)).

In the diapause, the total number of foragers increased from 8:00 to 11:00. The resource income remained constant from 11:00 to 13:00, when it started decreasing until 18:00 (Figure 2(b)). The nectar collection pattern was similar to the pattern of the total number of bees bringing resources to the colony. During the reproductive phase it was nearly constant along the day in both colonies (Figure 3(a)). From 8:00 to 11:00 it increased and remained constant until 16:00, when it decreased slightly.

In the diapause (Figure 3(b)), the collection of this resource increased from 8:00 to 11:00 and showed a peak between 11:00 and 12:00 in colony 1, but in colony 2 this peak lasted until 13:00. In general, the collection of nectar started to decrease after this peak until cessation.

Although distinct patterns in nectar collection in the two phases were found along the day, there was no difference 


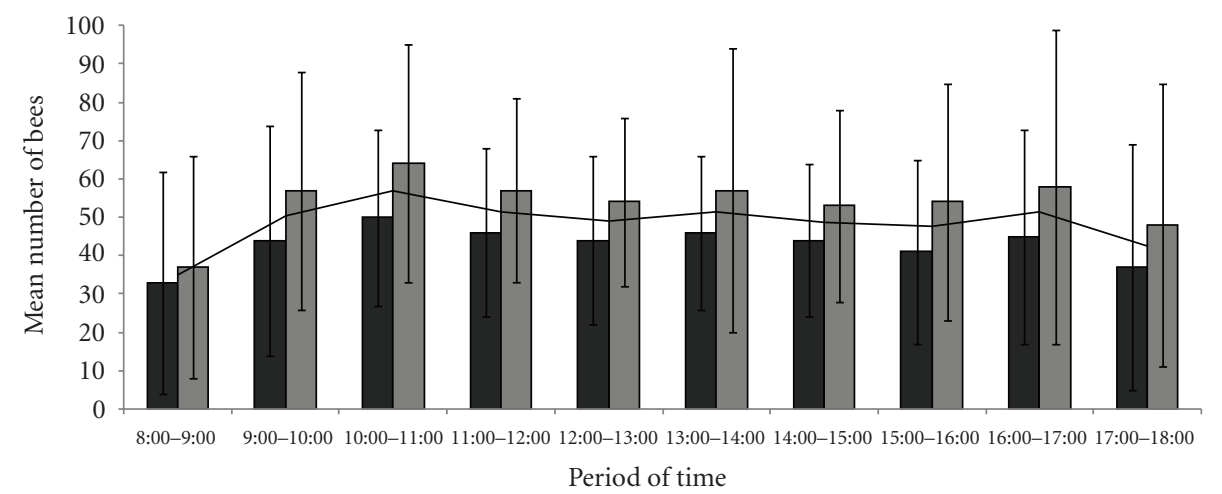

$$
\begin{aligned}
& \text { Col } 1 \\
& \square \text { Col } 2 \\
& - \text { Mean col 1/2 }
\end{aligned}
$$

(a)

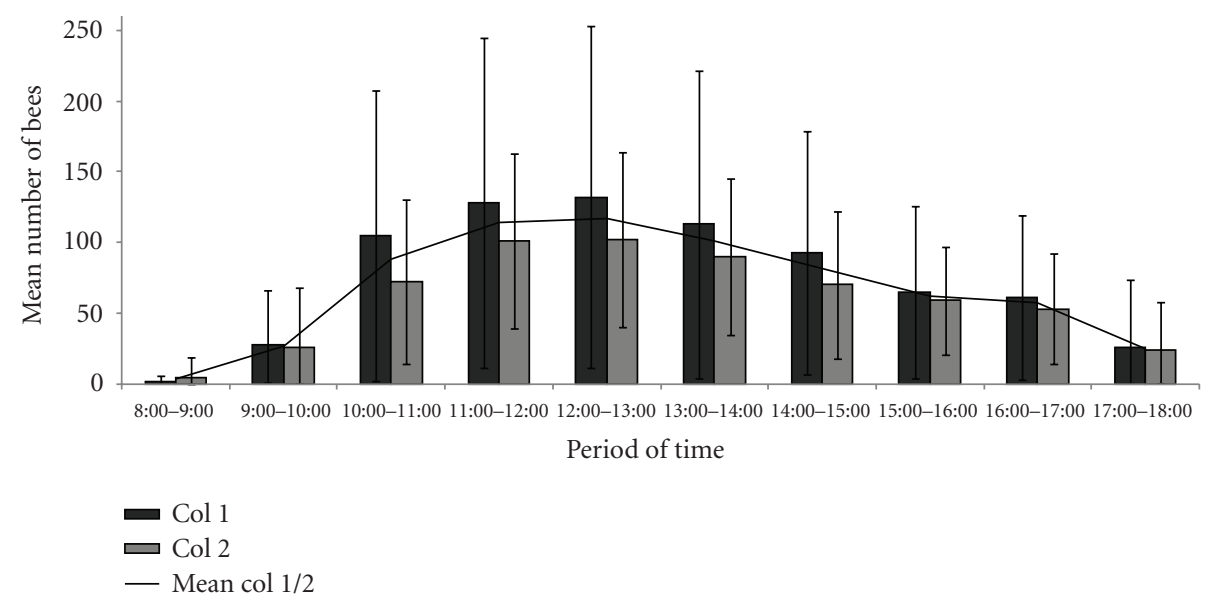

(b)

FIgURe 3: Nectar collection patterns of two colonies of Plebeia remota in the reproductive phase (a) and in the diapause (b).

between the total number of bees collecting nectar in the reproductive phase and in the diapause (Wilcoxon sign-rank test, colony $1: P>.05$; colony $2: P>.05)$.

The pollen collection pattern also showed differences between the two phases (Figure 4). In the reproductive phase the pollen collection showed a peak at the beginning of the morning, between 8:00 and 10:00. After that, pollen collection decreased along the day. The diapause was characterized by a low number of bees bringing pollen to the nest (Figure 4(b)). The number of bees collecting pollen increased between 8:00 and 11:00, remaining nearly constant for the rest of the day. There was a statistically significant difference between the total number of bees collecting pollen in the reproductive phase and in the diapause (Wilcoxon sign-rank test, colony 1: $P<.05$; colony $2: P<.05)$. The total number of bees bringing pollen to the nest in the reproductive phase was higher than in the diapause.

Resin foraging in the reproductive phase was constant along the day (Figure 5(a)). In the diapause, this activity was nearly constant along the day, with exception of few periods of time (Figure 5(b)).
There was a significant difference between the total number of bees collecting resin in the reproductive phase and in the diapause (Mann-Whitney test, colony 1: $P<.05$; colony 2: $P<.05)$. However, different situations occurred in each colony. In colony 1 , the total number of bees bringing resin to the nest in the reproductive phase was higher than in the diapause. In colony 2, the opposite was found (Figure 5).

The garbage removal in the reproductive phase and in the diapause was concentrated at the end of the day, after 15:00 (Figure 6). In general, it increased along the day. The total number of foragers removing garbage during the reproductive phase was smaller than during diapause in colony 1 (Mann-Whitney test, $P<.05$ ), but in colony 2 the opposite was found (Mann-Whitney test, $P<.05$; Figure 6 ).

There was a difference in the number of foraging trips for the different resources in the two phases in the two colonies (Kruskall-Wallis test, $P<.05$ ). Nectar was always the most collected resource (Figure 7). In the reproductive phase, pollen was the second most collected resource (Figures 7(a) and $7(b))$. In the diapause, different situations were found regarding pollen and resin collection. In colony 1 , pollen 


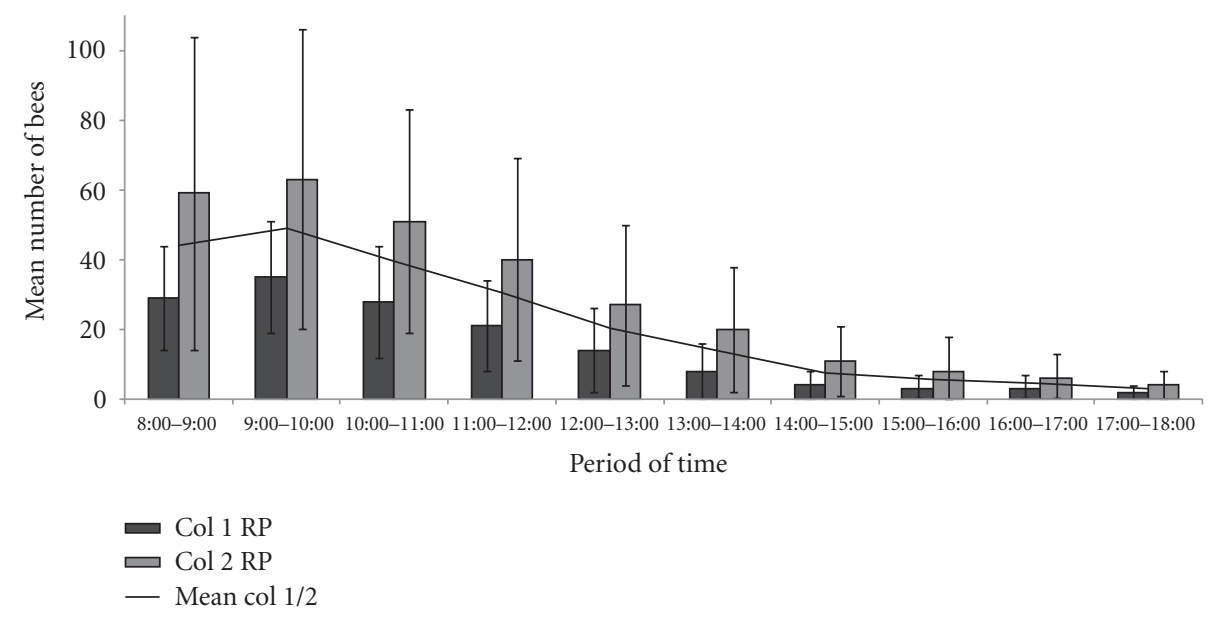

(a)

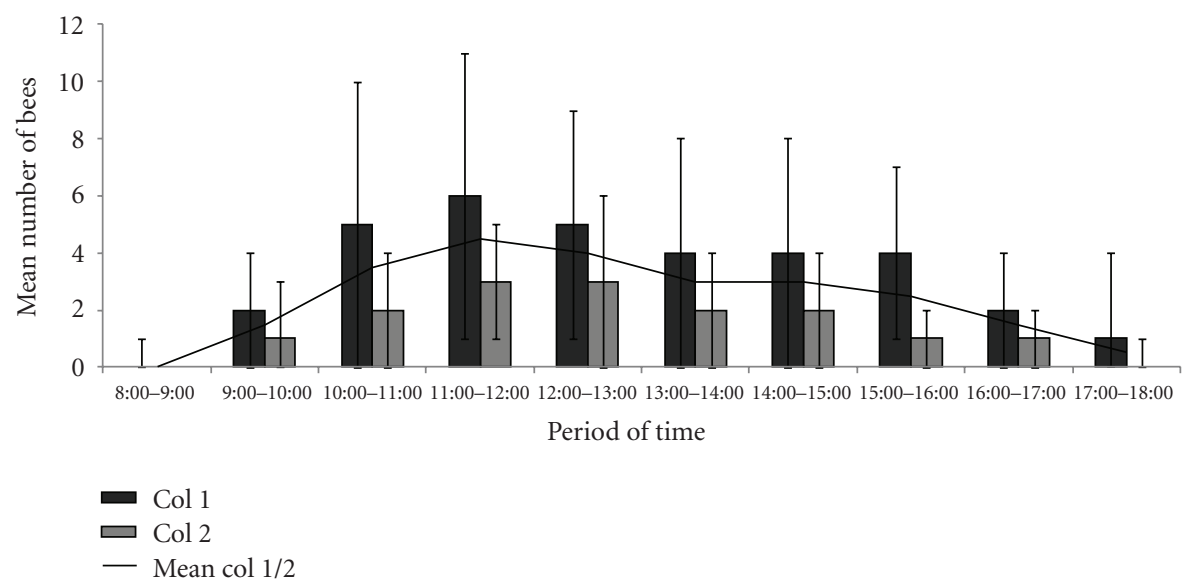

(b)

Figure 4: Pollen collection patterns of two colonies of Plebeia remota in the reproductive phase (a) and in the diapause (b).

collection was greater than resin collection (Mann-Whitney test, $Z=6.7$ and $P<.05$; Figures $7(\mathrm{a})$ and $7(\mathrm{c}))$, however, colony 2 had the opposite behavior (Mann-Whitney test, $Z=$ 6.1 and $P<.05$; Figures $7(\mathrm{~b})$ and $7(\mathrm{~d}))$. Garbage removal was more frequent when the resource (nectar, pollen, and resin) collection decreased at the end of the day (between 16:00 and 17:00) both in the reproductive phase and in the diapause (Figure 7).

3.2. Flight Activity and Climatic Factors. The air temperature and the relative humidity in the reproductive phase were different from the diapause (Mann-Whitney test, $P<.00$; Table 1).

In the diapause, for colony 1 the minimum temperature for foraging was $14.7^{\circ} \mathrm{C}$ (only one entry) and for colony 2 it was $14.3^{\circ} \mathrm{C}$. No bees were observed foraging below these temperatures. In the reproductive phase, none of the temperatures restricted the foraging behavior.

As expected, air temperature and relative humidity were always correlated (Table 1 ). In the reproductive phase and in the diapause, the total number of incoming workers depended on the air temperature and relative humidity (Table 2). The flight activity depended more on the temperature in the diapause than in the reproductive phase (higher $r$ values). The partial correlation between the total number of incoming trips and the relative humidity was not statistically significant for colony 1 in the reproductive phase and for colony 2 in the diapause (Table 2).

Nectar collection also depended on the air temperature. However, only the partial correlation between nectar collection and relative humidity in colony 1 in the diapause were statistically significant. Nectar collection was highly correlated with the total incoming trips in the colony (Table 2).

Pollen collection depended on the air temperature in the diapause, but not in the reproductive phase. In contrast, it depended on the air relative humidity in both phases. This activity was correlated with the total number of entrances in the colony only in the diapause (Table 2).

In colony 1 , resin collection showed a relationship with the temperature only in the diapause. In colony 2 , on the other hand, this activity depended to a minor extend on the temperature in both phases. The partial correlation between 


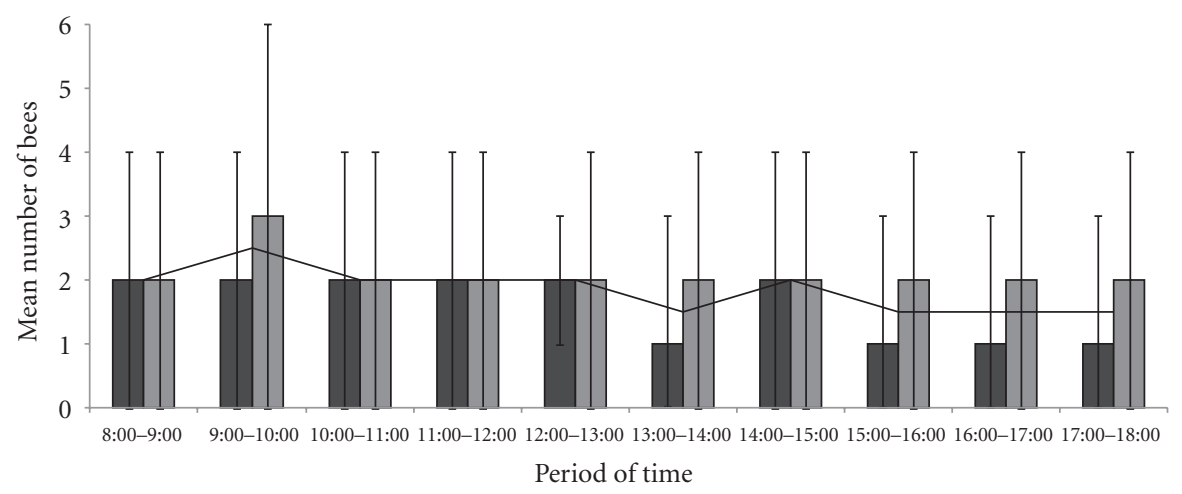

$$
\begin{aligned}
& \text { Col } 1 \\
& \square \text { Col } 2 \\
& - \text { Mean col 1/2 }
\end{aligned}
$$

(a)

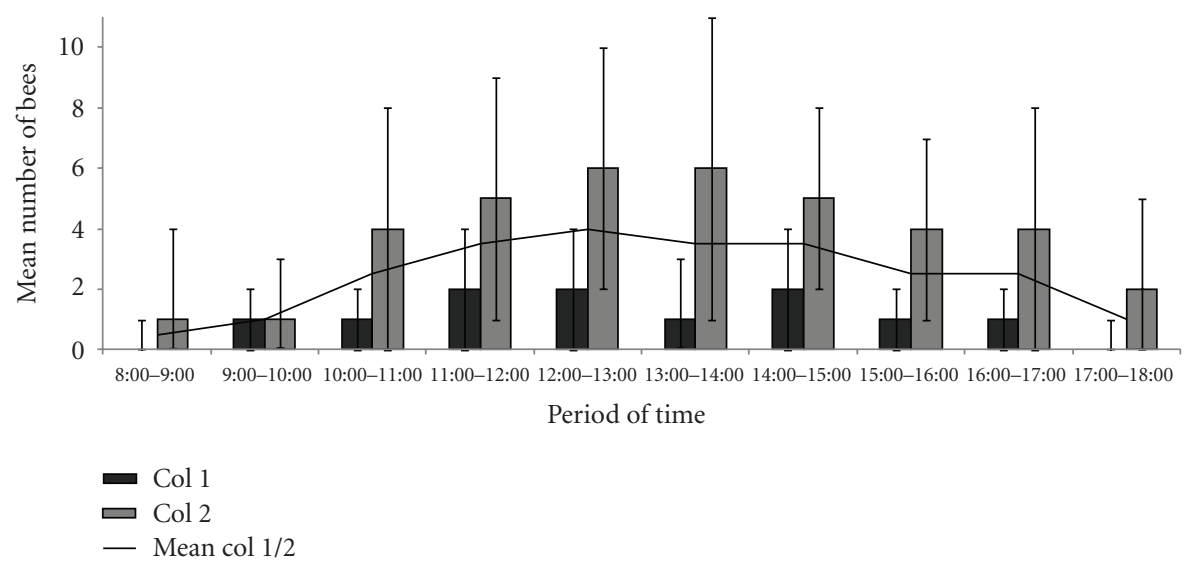

(b)

Figure 5: Resin collection patterns of two colonies of Plebeia remota in the reproductive phase (a) and in the diapause (b).

\begin{tabular}{|c|c|c|c|c|}
\hline & & & Colony 1 & Colony 2 \\
\hline \multirow{6}{*}{ Reproductive phase } & \multirow{3}{*}{ Temperature } & Mean & $24.5^{\circ} \mathrm{C} \pm 3.1^{\circ} \mathrm{C}$ & $24.5^{\circ} \mathrm{C} \pm 3.1^{\circ} \mathrm{C}$ \\
\hline & & Minimum & $17.5^{\circ} \mathrm{C}$ & $17.8^{\circ} \mathrm{C}$ \\
\hline & & Maximum & $32.4^{\circ} \mathrm{C}$ & $32.4^{\circ} \mathrm{C}$ \\
\hline & \multirow{3}{*}{ Relative humidity } & Mean & $64.6 \% \pm 15.2 \%$ & $64.8 \% \pm 15.4 \%$ \\
\hline & & Minimum & $26.3 \%$ & $24.5 \%$ \\
\hline & & Maximum & $93.3 \%$ & $93.3 \%$ \\
\hline \multirow{6}{*}{ Reproductive diapause } & \multirow{3}{*}{ Temperature } & Mean & $20.0^{\circ} \mathrm{C} \pm 3.2^{\circ} \mathrm{C}$ & $19.9^{\circ} \mathrm{C} \pm 3.2^{\circ} \mathrm{C}$ \\
\hline & & Minimum & $11.3^{\circ} \mathrm{C}$ & $11.6^{\circ} \mathrm{C}$ \\
\hline & & Maximum & $27.0^{\circ} \mathrm{C}$ & $26.7^{\circ} \mathrm{C}$ \\
\hline & \multirow{3}{*}{ Relative humidity } & Mean & $58.0 \% \pm 15.4 \%$ & $58.2 \% \pm 15.3 \%$ \\
\hline & & Minimum & $28.3 \%$ & $27.9 \%$ \\
\hline & & Maximum & $95.2 \%$ & $96.0 \%$ \\
\hline
\end{tabular}

TABle 1: Mean, minimum, and maximum temperatures $\left({ }^{\circ} \mathrm{C}\right)$ and relative humidity $(\%)$ during the reproductive phase and reproductive diapause. 


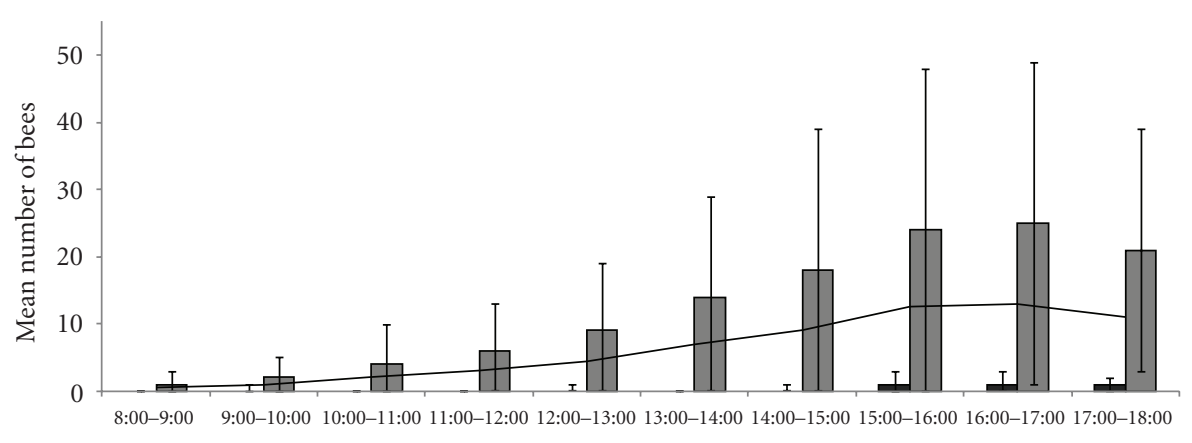

Period of time

Col 1

$\simeq \mathrm{Col} 2$

- Mean col 1/2

(a)

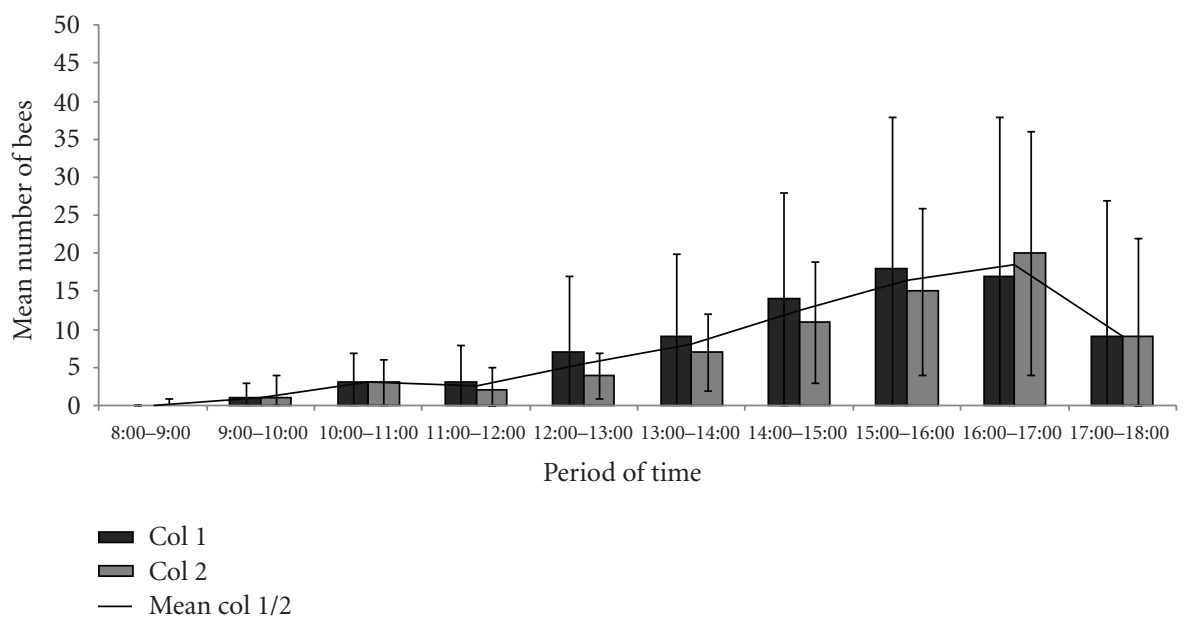

(b)

FIGURE 6: Garbage removal patterns of two colonies of Plebeia remota in the reproductive phase (a) and in the diapause (b).

resin collection and relative humidity was opposite in the two colonies. In colony 1 , this activity was not correlated with relative humidity in the reproductive phase, but it depended to a minor extent on this climatic factor in the diapause. In colony 2, resin collection depended on the relative humidity in the reproductive phase, but not in the diapause. Generally, this activity was not significantly correlated with the total number of incoming trips in the hive, with the exception in colony 1 during the diapause (Table 2).

The partial correlation between garbage removal and temperature was not significant only in colony 2 in the reproductive phase. In colony 1 , these two parameters showed a negative partial correlation in the reproductive phase. The partial correlation between garbage removal and relative humidity was not significant only in colony 1 in the reproductive phase. None of the partial correlations between this activity and the total number of incoming trips in the colony was statistically significant (Table 2).

3.3. Individual Activity of Foragers and Colony Rhythm. In the reproductive phase only eight $(2 \%)$ marked workers (from the ones we observed) in colony 1 and six (1.5\%) in colony 2 were observed while foraging (entering and exiting the colony). In the reproductive diapause, 131 (32.75\%) and $32(8 \%)$ marked bees were observed in colonies 1 and 2, respectively. Additional marked bees were observed exiting the colony; however they were not considered in the analyses because we do not know what foraging activity they performed.

Marked bees contributed little to nectar, pollen, and resin collecting during the reproductive phase and reproductive diapause (Table 3).

We observed no marked bees removing garbage from colonies 1 and 2 in the reproductive phase. In the reproductive diapause, we observed only one marked bee in each colony performing this activity. In colony 1 , this bee was responsible for only one removal flight $(0.04 \%)$, but in colony 2 , the observed bee was responsible for $7.21 \%$ of the removal flights.

We also verified if the marked bees were specialized (nectar, pollen, or resin foragers) or not. In the reproductive phase in colony $1,50 \%$ of the marked bees were nectar foragers $(37.5 \%$ collected only nectar and $12.5 \%$ collected 


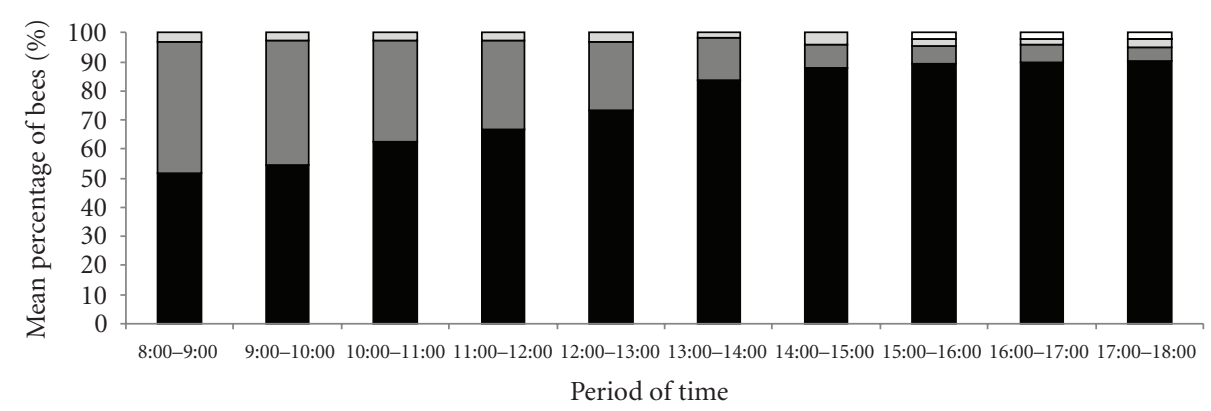
$\square$ Garbage
$\square$ Pollen
$\square$ Resin
- Nectar

(a)

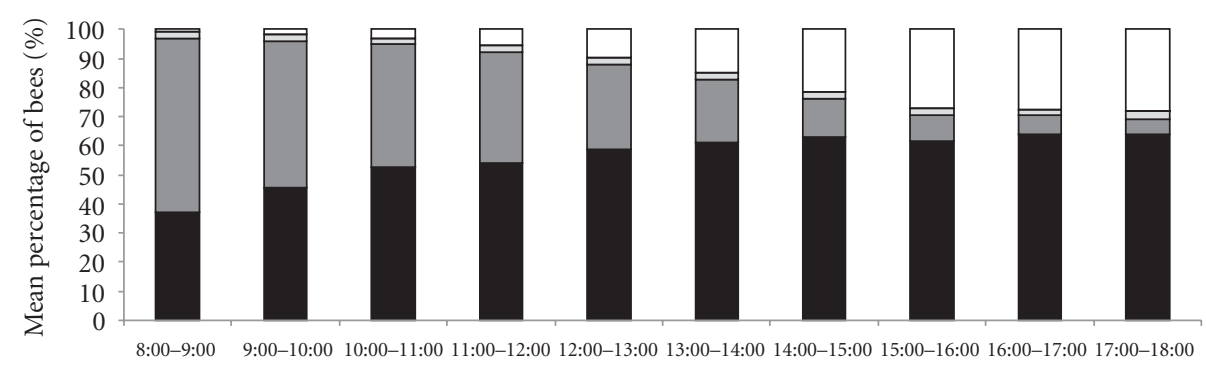
Period of time
$\square$ Garbage
$\square$ Pollen
$\square$ Resin
- Nectar

(b)

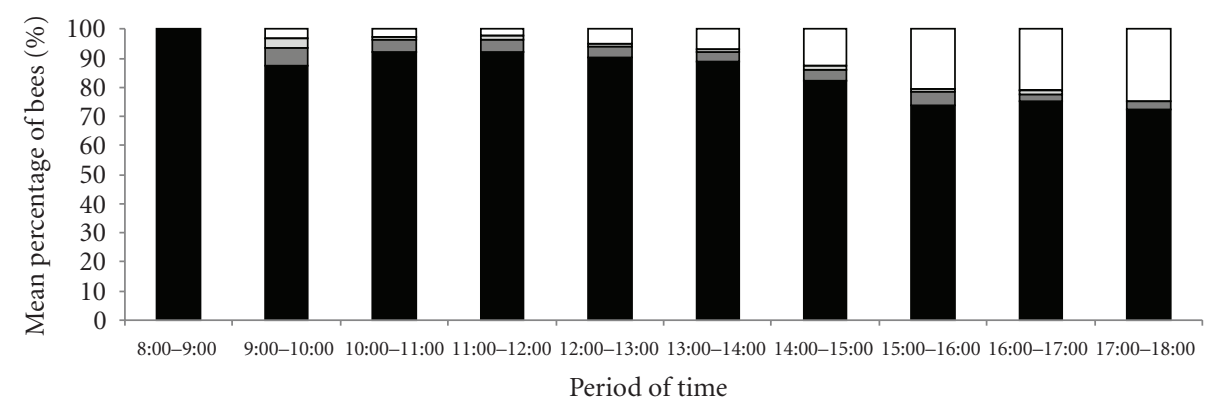
$\square$ Garbage
$\square$ Pollen
$\square$ Resin
- Nectar

(c)

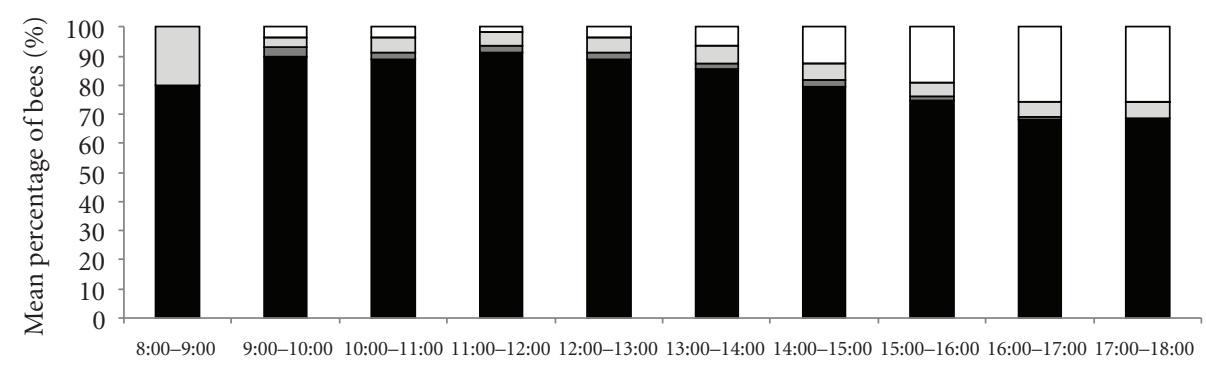
Period of time
$\square$ Garbage
$\square$ Pollen
$\square$ Resin
- Nectar

(d)

FIgURE 7: Mean percentage of Plebeia remota bees collecting nectar, pollen, and resin and removing garbage. Reproductive phase: (a) colony 1; (b) colony 2. Diapause: (c) colony 1; (d) colony 2. 
TABLE 2: Partial correlations ( $r_{a b, c}$, where $a$ and $b$ are the correlated variables and $c$ the controlled variable) between nectar (N), pollen (P), resin $(\mathrm{R})$, garbage $(\mathrm{G})$, and total number of incoming trips (TE) and temperature $(T)$ and relative humidity (RH); and Spearman correlations $\left(r_{a b}\right.$, where $a$ and $b$ are the correlated variables) between temperature $(T)$ and relative humidity $(\mathrm{RH})$, and between nectar $(\mathrm{N})$, pollen $(\mathrm{P})$, resin $(\mathrm{R})$, garbage $(\mathrm{G})$, and total number of incoming trips (TE) in the reproductive phase and in the diapause, in colonies 1 and 2 of Plebeia remota.

\begin{tabular}{|c|c|c|c|c|}
\hline & \multicolumn{2}{|c|}{ Colony 1} & \multicolumn{2}{|c|}{ Colony 2} \\
\hline & $r_{\text {reproductive phase }}$ & $r_{\text {diapause }}$ & $r_{\text {reproductive phase }}$ & $r_{\text {diapause }}$ \\
\hline$r_{T \mathrm{RH}}$ & $-0.7287^{*}$ & $-0.8993^{*}$ & $-0.7236^{*}$ & $-0.8969^{*}$ \\
\hline$r_{\mathrm{N} T, \mathrm{RH}}$ & $0.2824^{*}$ & $0.4135^{*}$ & $0.2823^{*}$ & $0.2188^{*}$ \\
\hline$r_{\mathrm{NRH}, T}$ & $-0.0505^{\mathrm{ns}}$ & $0.1553^{*}$ & $0.0294^{\mathrm{ns}}$ & $0.0846^{\mathrm{ns}}$ \\
\hline$r_{\mathrm{NTE}}$ & $0.8346^{*}$ & $0.9895^{*}$ & $0.7543^{*}$ & $0.9923^{*}$ \\
\hline$r_{\mathrm{P} T, \mathrm{RH}}$ & $-0.0511^{\mathrm{ns}}$ & $0.3584^{*}$ & $-0.0106^{\mathrm{ns}}$ & $0.3319^{*}$ \\
\hline$r_{\mathrm{PRH}, T}$ & $0.1368^{*}$ & $0.2957^{*}$ & $0.1243^{*}$ & $0.2470^{*}$ \\
\hline$r_{\mathrm{PTE}}$ & $0.5005^{\mathrm{ns}}$ & $0.6942^{*}$ & $0.6429^{\text {ns }}$ & $0.7468^{*}$ \\
\hline$r_{\mathrm{RT}, \mathrm{RH}}$ & $0.0996^{\mathrm{ns}}$ & $0.4580^{*}$ & $0.1697^{*}$ & $0.1862^{*}$ \\
\hline$r_{\mathrm{RRH}, T}$ & $-0.0261^{\mathrm{ns}}$ & $0.1565^{*}$ & $0.2750^{*}$ & $0.0742^{\text {ns }}$ \\
\hline$r_{\mathrm{RTE}}$ & $0.3524^{\mathrm{ns}}$ & $0.7751^{*}$ & $-0.0116^{\mathrm{ns}}$ & $0.5223^{\text {ns }}$ \\
\hline$r_{\mathrm{GT}, \mathrm{RH}}$ & $-0.1854^{*}$ & $0.2460^{*}$ & $0.0478^{\mathrm{ns}}$ & $0.2256^{*}$ \\
\hline$r_{\mathrm{GRH}, T}$ & $-0.0979^{\mathrm{ns}}$ & $0.0546^{*}$ & $0.1513^{*}$ & $0.1749^{*}$ \\
\hline$r_{\mathrm{GTE}}$ & $-0.0183^{\mathrm{ns}}$ & $0.6354^{\mathrm{ns}}$ & $0.2903^{\mathrm{ns}}$ & $0.5973^{\text {ns }}$ \\
\hline$r_{\mathrm{TE} T, \mathrm{RH}}$ & $0.1914^{*}$ & $0.4539^{*}$ & $0.1816^{*}$ & $0.2512^{*}$ \\
\hline$r_{\mathrm{TE}} \mathrm{RH}, T$ & $0.0279^{\text {ns }}$ & $0.1734^{*}$ & $0.1588^{*}$ & $0.1152^{\mathrm{ns}}$ \\
\hline
\end{tabular}

${ }^{*}$ statistically significant $(P<.05)$; ${ }^{\text {ns }}$ not statistically significant $(P>.05)$.

TABLE 3: Total number of incoming trips of nectar, pollen, and resin and the percentage of marked bees that performed these activities during the reproductive phase and reproductive diapause in colonies 1 and 2 of Plebeia remota.

\begin{tabular}{|c|c|c|c|c|c|}
\hline & & \multicolumn{2}{|c|}{ Colony 1} & \multicolumn{2}{|c|}{ Colony 2} \\
\hline & & $\begin{array}{l}\text { Total number of } \\
\text { incoming trips }\end{array}$ & $\begin{array}{l}\% \text { of marked bees } \\
\text { performing the } \\
\text { activity }\end{array}$ & $\begin{array}{l}\text { Total number of } \\
\text { incoming trips }\end{array}$ & $\begin{array}{l}\% \text { of marked bees } \\
\text { performing the } \\
\text { activity }\end{array}$ \\
\hline \multirow{3}{*}{ Reproductive phase } & Nectar & 12332 & 0.30 & 15364 & 0.06 \\
\hline & Pollen & 4406 & 0.36 & 8483 & 0.32 \\
\hline & Resin & 466 & 0 & 627 & 0 \\
\hline \multirow{3}{*}{ Reproductive diapause } & Nectar & 22316 & 8.0 & 17291 & 2.76 \\
\hline & Pollen & 974 & 5.85 & 472 & 0.21 \\
\hline & Resin & 349 & 1.72 & 1114 & 0.09 \\
\hline
\end{tabular}

also pollen), $25 \%$ pollen foragers, and $25 \%$ were nonspecialized (collected nectar and pollen). In colony 2, 66.7\% of the marked bees were pollen foragers and $33.3 \%$ were nonspecialized (collected nectar and pollen).

In the reproductive phase, $94.6 \%$ of the marked bees were nectar foragers in colony 1 (86.2\% collected only nectar and $8.4 \%$ collected also pollen or resin) and $96.9 \%$ in colony 2 (87.5\% collected only nectar and $9.4 \%$ collected also pollen), respectively. In colony $1,1.5 \%$ of the marked bees were pollen foragers in this phase and the rest was not specialized. In colony $2,3.1 \%$ of the marked bees were specialized in garbage removal.

The period of time that a marked bee foraged for was variable. In the reproductive phase foragers of colony 1 collected nectar for an average of 2.2 days (standard deviation: 1.5 days; $n=6$; maximum: four days) and pollen for 1.4 days (standard deviation: 0.9 days; $n=5$; maximum: three days). The mean number of days that the bees foraged (collected any resource or removed garbage) was 2.3 (standard deviation: 2.1 days; $n=8$; maximum: six days). In colony 2 we observed only two nectar foragers; one foraged for two days and the other for three. The bees foraged for pollen for an average of 2.7 days (standard deviation: 1.6 days; $n=6$; maximum: five days). The mean number of days that the bees foraged (collected any resource or removed garbage) was 3.3 (standard deviation: 2.3 days; $n=6$; maximum: six days).

In the reproductive diapause, foragers of colony $1 \mathrm{col}-$ lected nectar for an average of 3.3 days (standard deviation: 3.5 days; $n=126$; maximum: 16 days), pollen for 1.9 days (standard deviation: 1.1 days; $n=16$; maximum: 4 days) and resin for 1.3 days (standard deviation: 0.5 days; $n=4$; maximum: 2 days). The mean number of days that the bees foraged (collected any resource or removed garbage) was 3.4 


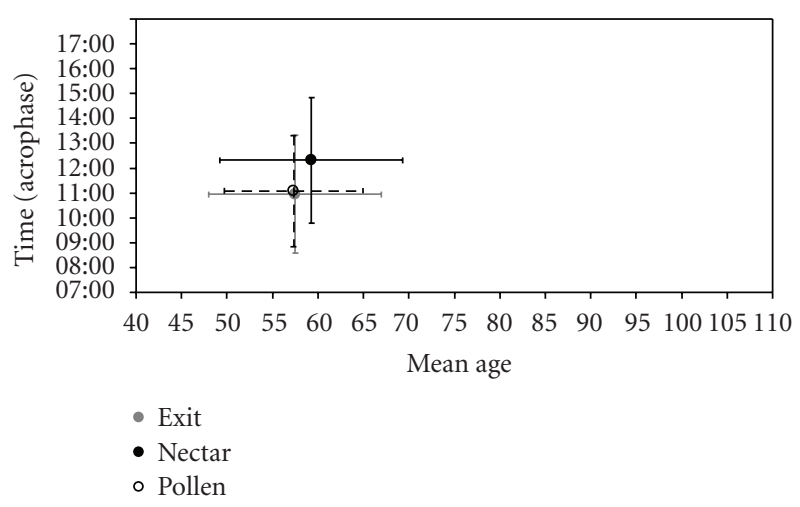

(a)

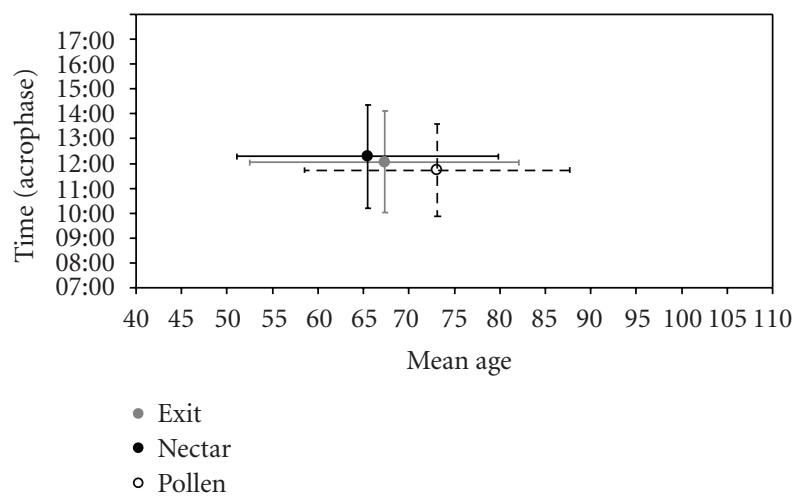

(b)

FIGURE 8: Acrophases with their respectives angular deviations ( $y$ axis) and mean ages with their respectives standard deviations ( $x$ axis) of nectar and pollen foraging and exit of marked bees of colony 1 of Plebeia remota, in the reproductive phase (a) and reproductive diapause (b).

(standard deviation: 3.6 days; $n=131$; maximum: 16 days). In colony 2 , the foragers collected nectar for an average of 4.4 days (standard deviation: 3.6 days; $n=31$; maximum: 13 days). We observed only two pollen foragers; one foraged for one day and the other for two. Only one bee collected resin and did it for one day. Another marked bee removed garbage from the colony for five days. The mean number of days that the bees foraged (collected any resource or removed garbage) was 4.5 (standard deviation: 3.5 days; $n=32$; maximum: 13 days).

Although a great variability was observed as to age of marked bees, the foragers of the reproductive diapause were older than the foragers from the reproductive phase (Figures 8 and 9, Table 4) in both colonies.

Acrophases were detected in nectar, pollen, and exit of marked bees (Table 4). These acrophases occurred in different times in the reproductive phase and diapause, with the exception of nectar collection (Figures 8 and 9, Table 4). The acrophase of pollen collection occurred earlier in the reproductive phase (Table 4), but the variation around it (angular deviation) was similar between the two phases (Table 4).

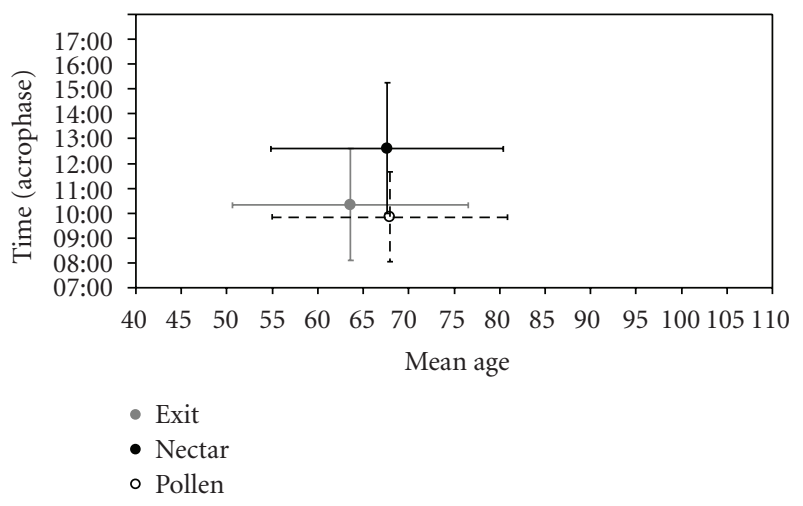

(a)

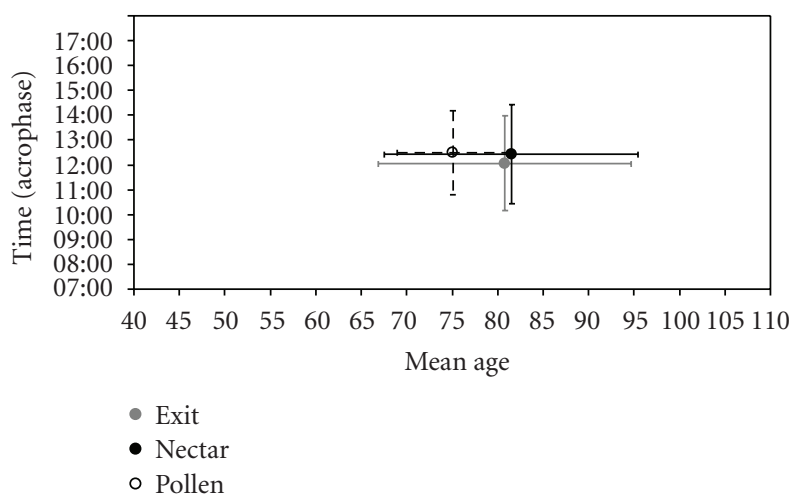

(b)

FIgURE 9: Acrophases with their respectives angular deviations ( $y$ axis) and mean ages with their respectives standard deviations ( $x$ axis) of nectar and pollen foraging and exit of marked bees of colony 2 of Plebeia remota, in the reproductive phase (a) and reproductive diapause (b).

We compared the foraging of marked bees with the colony foraging (marked and nonmarked bees observed). The acrophase of the marked foragers was within the interval of the acrophases of the colony foraging activity (Table 5). This indicated that the foraging activity of the marked bees is representative of the foraging activity of the colony.

3.4. Other Behavioral Observations. We observed the occurrence of nectar transfer between a forager and other bee that was in the tube. This behavior was not quantified, because it was not the aim of the observations, but tropholaxis was seen many times in the entrance tube. Sometimes the forager did tropholaxis with other bee in the tube as soon as it arrived and left the tube immediately. Hence, there is task partitioning in nectar collection in P. remota.

The garbage removal is also a task that is partitioned among workers of $P$. remota. We observed that one or two workers remained in the tube carrying a pellet of garbage with their mandibles. These workers passed the pellet to other workers that were in the entrance tube. Those caught the pellet with their first pair of legs, hold it with their mandibles and then flew out of the colony. Many times an 
TABle 4: Acrophases (Ac; hr:min) and angular deviations (AD; hr:min), mean ages (MA; days), standard deviations (SD; days), minimum (MinA) and maximum ages (MaxA), mean vectors $(r)$, number of activities (NA), and number of marked bees observed (Nobs) in the nectar $(\mathrm{N})$ and pollen $(\mathrm{P})$ foraging $(\mathrm{F})$ and in the exit $(\mathrm{E})$ of the marked bees of colonies 1 and 2 of Plebeia remota, in the reproductive diapause (RD) and reproductive phase (RP).

\begin{tabular}{|c|c|c|c|c|c|c|c|c|c|}
\hline & & $\mathrm{F}$ & $\mathrm{Ac} \pm \mathrm{AD}$ & $\mathrm{MA} \pm \mathrm{SD}$ & $\operatorname{Min} \mathrm{A}$ & MaxA & $r$ & NA & Nobs \\
\hline \multirow{6}{*}{ Colony 1} & \multirow{3}{*}{$\mathrm{RD}$} & $E$ & $12: 04 \pm 02: 02$ & $67,3 \pm 14,8$ & 42 & 105 & 0,856 & 1469 & 129 \\
\hline & & $\mathrm{N}$ & $12: 17 \pm 02: 05$ & $65,4 \pm 12,4$ & 42 & 95 & 0,851 & 1791 & 128 \\
\hline & & $\mathrm{P}$ & $11: 45 \pm 1: 51$ & $73,1 \pm 14,6$ & 50 & 101 & 0,882 & 58 & 16 \\
\hline & \multirow{3}{*}{$\mathrm{RP}$} & $\mathrm{E}$ & $10: 57 \pm 02: 23$ & $57,5 \pm 9,5$ & 38 & 73 & 0,804 & 42 & 9 \\
\hline & & $\mathrm{N}$ & $12: 19 \pm 02: 32$ & $59,2 \pm 10,0$ & 44 & 78 & 0,779 & 37 & 6 \\
\hline & & $\mathrm{P}$ & $11: 05 \pm 02: 14$ & $57,3 \pm 7,7$ & 48 & 70 & 0,827 & 16 & 5 \\
\hline \multirow{6}{*}{ Colony 2} & \multirow{3}{*}{$\mathrm{RD}$} & $E$ & $12: 04 \pm 01: 55$ & $80,8 \pm 13,9$ & 55 & 107 & 0,874 & 455 & 32 \\
\hline & & $\mathrm{N}$ & $12: 26 \pm 01: 59$ & $81,5 \pm 13,9$ & 55 & 107 & 0,864 & 481 & 32 \\
\hline & & $\mathrm{P}$ & $12: 30 \pm 01: 41$ & $75,0 \pm 6,1$ & 68 & 79 & 0,903 & 6 & 2 \\
\hline & \multirow{3}{*}{$\mathrm{RP}$} & $\mathrm{E}$ & $10: 21 \pm 02: 15$ & $63,6 \pm 12,9$ & 43 & 79 & 0,825 & 27 & 5 \\
\hline & & $\mathrm{N}$ & $12: 37 \pm 02: 37$ & $67,6 \pm 12,8$ & 45 & 76 & 0,763 & 10 & 2 \\
\hline & & $\mathrm{P}$ & $09: 52 \pm 01: 49$ & $67,9 \pm 12,9$ & 43 & 90 & 0,885 & 27 & 6 \\
\hline
\end{tabular}

TABLE 5: Acrophases (Ac) and angular deviations (AD) of the total number of bees collecting nectar and pollen, and of the marked bees of colonies 1 and 2 of Plebeia remota, in the reproductive phase and diapause.

\begin{tabular}{|c|c|c|c|c|}
\hline & Phase & Resource & Bees & $\mathrm{Ac} \pm \mathrm{AD}$ \\
\hline \multirow{8}{*}{ Colony 1} & \multirow{4}{*}{ Reproductive phase } & \multirow{2}{*}{ Nectar } & Colony & $12: 28 \pm 02: 39$ \\
\hline & & & Marked & $12: 19 \pm 02: 32$ \\
\hline & & \multirow{2}{*}{ Pollen } & Colony & $10: 11 \pm 02: 00$ \\
\hline & & & Marked & $11: 05 \pm 02: 14$ \\
\hline & \multirow{4}{*}{ Reproductive diapause } & \multirow{2}{*}{ Nectar } & Colony & $12: 32 \pm 02: 01$ \\
\hline & & & Marked & $12: 17 \pm 02: 05$ \\
\hline & & \multirow{2}{*}{ Pollen } & Colony & $12: 25 \pm 02: 04$ \\
\hline & & & Marked & $11: 45 \pm 01: 51$ \\
\hline \multirow{8}{*}{ Colony 2} & \multirow{4}{*}{ Reproductive phase } & \multirow{2}{*}{ Nectar } & Colony & $12: 32 \pm 02: 39$ \\
\hline & & & Marked & $12: 37 \pm 02: 37$ \\
\hline & & \multirow{2}{*}{ Pollen } & Colony & $10: 17 \pm 02: 04$ \\
\hline & & & Marked & $09: 52 \pm 01: 49$ \\
\hline & \multirow{4}{*}{ Reproductive diapause } & \multirow{2}{*}{ Nectar } & Colony & $12: 38 \pm 2: 05$ \\
\hline & & & Marked & $12: 26 \pm 01: 59$ \\
\hline & & \multirow{2}{*}{ Pollen } & Colony & $12: 10 \pm 01: 51$ \\
\hline & & & Marked & $12: 30 \pm 01: 41$ \\
\hline
\end{tabular}

incoming forager caught the pellet from a worker and flew out of the colony immediately. Sometimes the worker that holds the pellet could resist and not give the pellet to the other bee. In this case, they pulled the pellet like in "tug of war" (rope pulling) or the worker ran away from the other bee that tried to catch the pellet while the other chased her.

\section{Discussion}

The foraging pattern of the reproductive phase was different from the one found in the diapause. Although we found some differences between times of the day, the foraging activity of the bees, during the reproductive phase, was nearly constant. Nevertheless, this activity in the diapause was more concentrated in the middle of the day, as already found by Imperatriz-Fonseca et al. [29] and Hilário [23]. The foraging pattern of $P$. saiqui, another species that presents diapause, was also different in the two phases (Table 4). These differences may be caused by environmental factors, probably temperature, as discussed later. Another factor that can influence the foraging activity of bees is the variation in the quantity and quality of food resources between days or seasons [2].

In the reproductive phase, the nectar collection was nearly constant along the day, as well as the general foraging pattern of the colonies. This is expected because most of the foraging activity of the colonies was of nectar bringing foragers. Other stingless bee species also present this pattern (Table 6). In the reproductive diapause, nectar was collected more in the middle of the day (11:00-13:00). Another bee species also showed this peak of nectar collection (Table 6). 
TABLE 6: Peaks of the different foraging activities of different species of stingless bees (Meliponini) that present or do not present reproductive diapause.

\begin{tabular}{|c|c|c|c|c|c|c|c|}
\hline Species & $\begin{array}{l}\text { Reproductive } \\
\text { diapause }\end{array}$ & $\begin{array}{c}\text { General } \\
\text { foraging peak }\end{array}$ & $\begin{array}{c}\text { Nectar foraging } \\
\text { peak }\end{array}$ & $\begin{array}{c}\text { Pollen foraging } \\
\text { peak }\end{array}$ & $\begin{array}{c}\text { Resin foraging } \\
\text { peak }\end{array}$ & $\begin{array}{l}\text { Detritus } \\
\text { removal }\end{array}$ & Reference \\
\hline $\begin{array}{l}\text { Tetragonisca } \\
\text { angustula }\end{array}$ & No & - & None & - & $\begin{array}{l}\text { End of morn- } \\
\text { ing/beginning } \\
\text { of afternoon }\end{array}$ & - & {$[27]$} \\
\hline Melipona fasciata & No & - & $\begin{array}{l}\text { Middle of the } \\
\text { day }\end{array}$ & - & $\begin{array}{c}\text { Beginning of } \\
\text { morning/after } \\
\text { 15:00 }\end{array}$ & - & {$[27]$} \\
\hline Melipona beecheii & No & - & $\begin{array}{l}\text { Middle of the } \\
\text { day }\end{array}$ & - & $\begin{array}{c}\text { Beginning of } \\
\text { morning/after } \\
15: 00\end{array}$ & - & {$[27]$} \\
\hline Melipona favosa & No & - & $\begin{array}{l}\text { Middle of the } \\
\text { day }\end{array}$ & - & - & - & {$[27]$} \\
\hline $\begin{array}{l}\text { Melipona bicolor } \\
\text { bicolor }\end{array}$ & No & - & - & $\begin{array}{l}\text { Begining of } \\
\text { morning }\end{array}$ & $\begin{array}{c}\text { End of } \\
\text { afternoon }\end{array}$ & $\begin{array}{c}\text { End of } \\
\text { afternoon }\end{array}$ & {$[28]$} \\
\hline Melipona scutellaris & No & - & None & $\begin{array}{l}\text { Beginning of } \\
\text { morning }\end{array}$ & None & Morning & [29] \\
\hline $\begin{array}{l}\text { Melipona marginata } \\
\text { obscurior }\end{array}$ & No & - & $\begin{array}{l}\text { Middle of the } \\
\text { day }\end{array}$ & - & - & - & {$[30]$} \\
\hline Melipona asilvai & No & - & $\begin{array}{l}\text { Middle of the } \\
\text { day }\end{array}$ & - & - & - & {$[31]$} \\
\hline $\begin{array}{l}\text { Meliponula } \\
\text { ferruginea }\end{array}$ & No & - & None & - & - & Morning & {$[32]$} \\
\hline Meliponula nebulata & No & - & None & - & - & Morning & {$[32]$} \\
\hline Plebeia pugnax & No & & $\begin{array}{l}\text { Middle of the } \\
\text { day }\end{array}$ & $\begin{array}{l}\text { Beginning of } \\
\text { morning }\end{array}$ & None & $\begin{array}{c}\text { S: } \\
\text { 11:00-13:00 } \\
\text { W/A: } \\
\text { 15:00-17:00 }\end{array}$ & {$[5,33]$} \\
\hline Plebeia saiqui & Yes & $\begin{array}{l}\text { RP: 11:00-12:00 } \\
\text { RD: 13:00-14:00 }\end{array}$ & - & $\begin{array}{l}\text { RP: beginning } \\
\text { of morning } \\
\text { RD: none }\end{array}$ & - & - & {$[11,12]$} \\
\hline \multirow[t]{2}{*}{ Plebeia remota } & \multirow[t]{2}{*}{ Yes } & RP: none & RP: none; & $\begin{array}{l}\text { RP: beginning } \\
\text { of morning }\end{array}$ & None & \multirow[t]{2}{*}{$\begin{array}{l}\text { End of } \\
\text { afternoon }\end{array}$} & \multirow[t]{2}{*}{ This study } \\
\hline & & $\begin{array}{c}\text { RD: around } \\
12: 00\end{array}$ & $\begin{array}{c}\text { RD: } \\
\text { 11:00-13:00 }\end{array}$ & RD: no & & & \\
\hline
\end{tabular}

Removal of detritus from the colonies occurred mainly at the end of the afternoon. We did not find a pattern in relation to the number of foragers performing this activity in the different colony phases (reproductive and diapause), because each colony behaved in a different way. This activity might be influenced more by the internal conditions than by external factors, like season of the year and climatic factors. Souza et al. [34] found a positive correlation between nectar and pollen income and garbage removal, and suggested that the growth of the colony influences directly the amount of garbage produced by the colonies. The peak of this activity occurs at different times of the day in different species (Table 6). The resin foraging is also different in distinct species (Table 6). In P. remota this activity occurred along the day, in both phases.

Besides the distinct daily foraging patterns between the reproductive period and diapause, we observed differential foraging efforts according to the resource, a new finding for the species studied. A similar number of bees bringing nectar to the colony was observed in the two phases, but the percentage of nectar in relation to the other resources collected was higher in the diapause. This might be a reflection of the differential allocation of foragers among different tasks. In the diapause the number of bees collecting pollen was lower compared to the reproductive phase, so the foragers concentrate their activity in nectar collection. On the other hand, nectar is the sugar source that provides energy for the bees. During diapause bees stay still inside the colony [17], but a large quantity of this resource may be needed when all colonies' activities restart. Although we did not quantify, we observed an increase in the number of storage pots with honey in the diapause and we did not observe pollen stored in the colonies. However, this increase in nectar storage may occur due to the decrease in consumption by the bees. In this phase there is a decrease in the colonies' population over time, since after the emergency 
of all the remaining brood, no bees will emerge until the end of the reproductive diapause and the development of the first brood when the reproductive phase begins again.

Nectar could also be needed in greater quantity during diapause because of thermoregulation. Apis mellifera individuals can maintain their corporal temperature when they have sugar in their crop [35]. We do not know whether this is true for $P$. remota or not, but if it is, honey is more needed during diapause, when it is colder (autumn and winter). These hypotheses need to be tested. Also it is possible that bees need nectar as a source of energy to forage [36].

We observed quantitative differences in pollen collection of the two phases. A greater number of incomes of this resource was observed in the reproductive phase and the percentage of bees doing this activity increased in relation to the other resources, although nectar incomes made the greatest percentage of the incomes in both phases. This difference in the number of bees foraging for pollen was also observed in P. saiqui [13].

Most bees rely on pollen as the main source of nitrogen and it is collected mainly to feed the larvae [3]. In A. mellifera, the quantity of brood and stored pollen influences the pollen foraging [37]. This might be the case of $P$. remota. In the diapause there is no cell construction and provisioning of these cells for queen oviposition. This might influence the decision of the foragers, as a higher percentage of pollen foragers was found in the reproductive phase.

Furthermore, there is the possibility that, as in $A$. mellifera [38], winter bees eat less pollen than summer bees. Hrassnigg and Crailsheim [39] state that A. mellifera workers respond to different quantities of brood adjusting their behavior and physiology, eating more or less pollen and altering their flight activity. The authors state that this allows that the winter bees live longer and work when there is brood in the colony again. This reduced need for pollen in $P$. remota during diapause may influence the pollen foraging in this species in a similar way that happens in honey bees and maybe this mechanism of regulating the life span is also present in this species, whereas the bees lived longer in the reproductive diapause, which occurs in winter.

Another similarity between $P$. remota and $P$. saiqui pollen foraging was the daily peak of this activity in the reproductive phase. In both species it occurred in the begining of the morning until $10 \mathrm{am}$, when it started to decrease until the end of the day [13]. In other stingless bee species a peak of pollen collection also occurred in the beginning of the morning (examples: M. scutellaris [13]; M. bicolor bicolor [10]; P. pugnax [7]).

Climatic factors such as air temperature and relative humidity influence the flight activity of bees, along internal conditions of the colony. The differences found in air temperature and relative humidity between the two phases may be one of the reasons of the distinct patterns observed in the colonies of P. remota. Generally, the flight activity of stingless bees is positively correlated with the air temperature and negatively correlated with relative humidity (P. saiqui [13]; M. marginata obscurior [33, 40]; M. asilvai [34]; Meliponula ferruginea and Meliponula nebulata [34]; Tetragonisca angustula [41]; M. marginata marginata [40]).
The same relationship was found by Hilário [23] for P. remota. However, we found weak relationships between these climatic factors and the different foraging activities of $P$. remota, when they were significant. This might be due to the type of analyses we made. We used partial correlation to describe these relationships. Partial correlation statistically corrects for the effect of a third variable which influences the variables involved in the original correlation [27]. We wanted to evaluate the effect of air temperature and relative humidity in the flight activity of $P$. remota, but these two climatic factors are highly correlated and with simple correlation it is not possible separate the effects of air temperature and relative humidity on this activity.

As Hilário [23], we found weaker relationships in summer (reproductive phase) than in winter (diapause). This might be because in the summer bees forage along the day (all temperatures registered), but in winter this activity occurs mainly in the middle of the day, when the temperatures are higher. Other climatic factors as wind [24] and rain [25] are also responsible for shaping the flight activity of the colonies.

The air temperature is a constraining factor. Bees must warm up before going out for foraging and waste removing. The minimum temperature that occurred during observations was in the diapause: $11.3^{\circ} \mathrm{C}$ for colony 1 and $11.6^{\circ} \mathrm{C}$ for colony 2. Flight activity was observed under $14.7^{\circ} \mathrm{C}$ for colony 1 and under $14.3^{\circ} \mathrm{C}$ for colony 2, indicating that temperatures under $14^{\circ} \mathrm{C}$ limits the flight activity of $P$. remota. This temperature is lower than the temperature found by Imperatriz-Fonseca et al. [29] $\left(16^{\circ} \mathrm{C}\right.$, but not in winter). However, Hilário [23] observed flight activity under $10.2^{\circ} \mathrm{C}$, indicating that the restraining temperature for the flight activity of this species is around $10^{\circ} \mathrm{C}$. Other species from these genera presented similar low temperatures for foraging (P. pugnax: $14^{\circ} \mathrm{C}$ [7]; P. saiqui: $11^{\circ} \mathrm{C}[14]$ ).

Kleinert-Giovannini and Imperatriz-Fonseca [40] observed that even under optimal climatic conditions for the flight activity of $M$. marginata marginata and $M$. marginata obscurior a decrease in this activity can occur, which indicates that there is a daily rhythm in it under favorable environmental conditions.

$P$. remota, as other eusocial bee species, presents an age dependent division of labor (age polyethism). Foraging is the final stage of the life of a worker and it begins around 30 days of life [13]. Van Benthem et al. [15] observed $46 \%$ of the marked workers performing foraging in autumn and winter. In this study, a similar percentage of bees (32.75\%) in colony 1 was observed performing this activity, though in colony 2 a lower percentage $(8 \%)$ was observed. The percentage of observed marked bees varies among studies (M. bicolor bicolor, 60\% [42]; Scaptotrigona postica, 40\% [43]; Friesella sp, 34\% [44]; M. compressipes fasciculata, 88.3\% [45]).

The age that the workers of $P$. remota became foragers varied from 43 to 90 days in the reproductive phase and from 42 to 107 days in the reproductive diapause. Van Benthem et al. [15] observed foragers of 30 to 87 days of age in the reproductive diapause, similar to our observations. The difference in the age of foragers of the two phases might be a reflection of the differential longevity of the bees in these 
phases, as they live longer, they start foraging later. P. remota winter bees live from 25 to $100 \%$ more than summer bees [15]. P. droryana workers were also observed for more than 100 days in the reproductive diapause and began to forage after 35 days of age [18].

In general Melipona species start to forage earlier than $P$. remota (M. compressipes fasciculata: 15 to 85 days of age [45]; M. beecheii: 16 to over 60 days of age [28]). S. postica workers became foragers on 20 to 60 days of age [43] and Friesella workers on 17 to 41 days of age [44].

M. beecheii nectar foragers foraged for three days (from two to four days) [28]. Generally, P. remota foragers collected nectar for a similar number of days in the reproductive phase and diapause, but the variation (up to 13 days, colony 2) in the reproductive diapause was greater than in this Melipona species. The pollen and resin foraging was performed in a shorter period when compared to M. beecheii [28]. Based on the previous studies and our results (M. bicolor bicolor: around 6 days [42]; M. compressipes fasciculata: mean of 10 days [44]; S. postica: 3 to 7 days [43]), in general stingless bee foragers perform their activities for less than 10 days.

In stingless bees, the foraging of the colony is based on the individual decision of the workers. Each has to decide when to start or to stop foraging. These decisions are taken using intrinsic information, as genetic information, memory, development and hormones, and extrinsic information, which comes from inside the colony (stored resources, information from other forager, odors, among others) or outside (flower availability and competition, for example) [9-11]. Although there are no studies on the influence of these factors on the foraging of P. remota, these factors might influence this activity in this species as well. Besides, the absence of the provisioning and oviposition process, one of the extrinsic information from inside the colony, shall be a key factor in the organization of this behavior in the reproductive diapause, as in this phase there are behavioral changes in the behavior of workers $[17,22]$ and, as we observed, of the foragers, noticed despite the difference in the proportion of nectar and pollen foragers between the phases.

Diel rhythms were found in the foraging behavior of the P. remota colonies, and when we compared the acrophase of nectar collection detected in this study with the acrophase of flight activity detected by Hilário [23], they are very similar. M. bicolor also present daily rhythms in flight activity [30]. Scaptotrigona aff depilis [46], and Apis mellifera [47] also present circadian rhythms, as the studies were done under controlled environmental conditions.

The nectar foraging is a partitioned task in $P$. remota, as in other stingless bee species (Melipona beecheii [29, 48], $M$. fasciata, M. favosa, Tetragonisca angustula [30], Trigona nigra, Plebeia frontalis, Scaptotrigona pectoralis and Nannotrigona perilampoides [48]). We also observed task partitioning in garbage removal, but it is almost unknown in stingless bees.

\section{Acknowledgment}

The authors thank CNPq (135074/2005-3 and 140169/20008) for financial support.

\section{References}

[1] S. F. Sakagami, "Stingless bees," in Social Insects Vol. III, H. R. Hermann, Ed., pp. 361-423, Academic Press, New York, NY, USA, 1982.

[2] S. W. Roubik, Ecology and Natural History of Tropical Bees, Cambridge University Press, New York, NY, USA, 1989.

[3] T. Eltz, C. A. Brühl, and C. Görke, "Collection of mold (Rhizopus sp.) spores in lieu of pollen by the stingless bee Trigona collina," Insectes Sociaux, vol. 49, no. 1, pp. 28-30, 2002.

[4] C. D. Michener, The Social Behavior of the Bees: A Comparative Study, Belknap Press of Harvard University Press, Cambridge, Mass, USA, 1974.

[5] C. M. L. Aguiar and C. A. Garófalo, "Nesting biology of Centris (Hemisiella) tarsata Smith (Hymenoptera, Apidae, Centridini)," Revista Brasileira de Entomologia, vol. 21, no. 3, pp. 477-486, 2004.

[6] C. M. L. Aguiar, C. A. Garófalo, and G. F. Almeida, "Biologia de nidificação de Centris (Hemisiella) trigonoides Lepeletier (Hymenoptera, Apidae, Centridini)," Revista Brasileira de Zoologia, vol. 23, no. 2, pp. 323-330, 2006.

[7] S. D. Hilário, V. L. Imperatriz-Fonseca, and A. M. Kleinert, "Responses to climatic factors by foragers of Plebeia pugnax Moure (in litt.) (Apidae, Meliponinae)," Revista Brasleira de Biologia, vol. 61, no. 2, pp. 191-196, 2001.

[8] A. Kleinert-Giovannini, "The influence of climatic factors on flight activity of Plebeia emerina Friese (Hymenoptera, Apidae, Meliponinae) in winter," Revista Brasileira de Entomologia, vol. 26, no. 1, pp. 1-13, 1982.

[9] J. C. Biesmeijer, M. G. L. van Nieuwstadt, S. Lukács, and M. J. Sommeijer, "The role of internal and external information in foraging decisions of Melipona workers (Hymenoptera: Meliponinae)," Behavioral Ecology and Sociobiology, vol. 42, no. 2, pp. 107-116, 1998.

[10] S. D. Hilário, V. L. Imperatriz-Fonseca, and A. M. P. Kleinert, "Flight activity and colony strentgh in the stingless bee Melipona bicolor bicolor (Apidae, Meliponinae)," Revista Brasileira de Biologia, vol. 60, no. 2, pp. 299-306, 2000.

[11] J. C. Biesmeijer and E. J. Slaa, "Information flow and organization of stingless bee foraging," Apidologie, vol. 35, no. 2, pp. 143-157, 2004.

[12] F. E. Hofstede and M. J. Sommeijer, "Influence of environmental and colony factors on the initial commodity choice of foragers of the stingless bee Plebeia tobagoensis (Hymenoptera, Meliponini)," Insectes Sociaux, vol. 53, no. 3, pp. 258-264, 2006.

[13] R. A. Pick and B. Blochtein, "Atividades de coleta e origem floral do pólen armazenado em colônias de Plebeia saiqui (Holmberg) (Hymenoptera, Apidae, Meliponinae) no sul do Brasil," Revista Brasileira de Zoologia, vol. 19, no. 1, pp. 289300, 2002.

[14] R. A. Pick and B. Blochtein, "Atividades de vôo de Plebeia saiqui (Holmberg) (Hymenoptera, Apidae, Meliponinae) durante o período de postura da rainha e em diapausa," Revista Brasileira de Zoologia, vol. 19, no. 3, pp. 827-839, 2002.

[15] F. D. van Benthem, V. L. Imperatriz-Fonseca, and H. H. Velthuis, "Biology of the stingless bee Plebeia remota (Holmberg): observations and evolutionary implications," Insectes Sociaux, vol. 42, no. 1, pp. 71-87, 1995.

[16] M. De F. Ribeiro, "Does the queen of Plebeia remota (Hymenoptera, Apidae, Meliponini) stimulate her workers to start brood cell construction after winter?" Insectes Sociaux, vol. 49, no. 1, pp. 38-40, 2002. 
[17] M. F. Ribeiro, V. L. Imperatriz-Fonseca, and P. S. Santos Filho, "A interrupção da construção de células de cria e postura em Plebeia remota (Holmberg) (Hymenoptera, Apidae, Meliponini)," in Apoidea Neotropica: Homenagem aos 90 Anos de Jesus Santiago Moure, G. A. R. Melo and I. Alves dos Santos, Eds., pp. 177-188, Editora UNESC, Criciúma, Brazil, 2003.

[18] Y. Terada, C. A. Garófalo, and S. F. Sakagami, "Age-survival curves for workers of two eusocial bees (Apis mellifera and Plebeia droryana) in a subtropical climate, with notes on worker polyethism in $P$. droryana," Journal of Apicultural Research, vol. 14, no. 3-4, pp. 161-170, 1975.

[19] L. A. Juliani, "Descrição do ninho e alguns dados biológicos sobre a abelha Plebeia Juliani Moure, 1962 (Hymenoptera, Apidae, Meliponinae)," Revista Brasileira de Entomologia, vol. 12, pp. 31-58, 1967.

[20] D. Wittmann, "Nest architecture, nest site preferences and distribution of Plebeia wittmanni (Moure \& Camargo, 1989) in Rio Grande do Sul, Brazil (Apidae: Meliponinae)," Studies on Neotropical Fauna \& Environment, vol. 24, no. 1, pp. 17-23, 1989.

[21] F. V. B. Borges and B. Blochtein, "Variação sazonal das condições internas de colônias de Melipona marginata obscurior Moure, no Rio Grande do Sul, Brasil," Revista Brasileira de Zoologia, vol. 23, no. 3, pp. 711-715, 2006.

[22] E. Périco, Comunicação química em cinco espécies do gênero Plebeia com ênfase nos mecanismos de defesa contra a abelha cleptobiótica Lestrimelitta limao (Hymenoptera: Apidae: Meliponinae), thesis, Universidade of São Paulo, São Paulo, Brazil, 1997.

[23] S. D. Hilário, Atividade de vôo e termorregulação de Plebeia remota (Holmberg, 1903) (Hymenoptera, Apidae, Meliponini), thesis, University of São Paulo, São Paulo, Brazil, 2005.

[24] S. D. Hilário, M. F. Ribeiro, and V. L. Imperatriz-Fonseca, "Efeito do vento sobre a atividade de vôo de Plebeia remota (Holmberg, 1903) (Apidae, Meliponini)," Biota Neotropica, vol. 7, no. 3, pp. 225-232, 2007.

[25] S. D. Hilário, M. F. Ribeiro, and V. L. Imperatriz-Fonseca, "Impacto da precipitação pluviométrica sobre a atividade de vôo de Plebeia remota (Holmberg, 1903) (Apidae, Meliponini)," Biota Neotropica, vol. 7, no. 3, pp. 135-143, 2007.

[26] S. F. Sakagami, "Techniques for the observation of behaviour and social organization of stingless bees by using a special hive," Papéis Avulsos do Departamento de Zoologia, vol. 18, no. 12, pp. 151-162, 1966.

[27] J. H. Zar, Biostatistical Analysis, Prentice Hall, New Jersey, NY, USA, 1999.

[28] J. C. Biesmeijer and E. Tóth, "Individual foraging, activity level and longevity in the stingless bee Melipona beecheli in Costa Rica (hymenoptera, apidae, meliponinae)," Insectes Sociaux, vol. 45, no. 4, pp. 427-443, 1998.

[29] V. L. Imperatriz-Fonseca, A. Kleinert-Giovannini, and J. M. Pires, "Climatic variations on the flight activity of Plebeia remota Holmberg (Hymenoptera, Apidae, Meliponinae)," Revista Brasileira de Entomologia, vol. 29, no. 3-4, pp. 427-434, 1985.

[30] L. L. M. de Bruijn and M. J. Sommeijer, "Colony foraging in different species of stingless bees (Apidae, Meliponinae) and the regulation of individual nectar foraging," Insectes Sociaux, vol. 44, no. 1, pp. 35-47, 1997.

[31] S. D. Hilário, M. Gimenes, and V. L. Imperatriz-Fonseca, "The influence of colony size in diel rhythms of flight activity of Melipona bicolor Lepeletier (Hymenoptera, Apidae, Meliponinae)," in Apoidea Neotropica: Homenagem aos 90 Anos de Jesus Santiago Moure, G. A. R. Melo and I. Alves dos Santos, Eds., pp. 191-197, Editora UNESC, Criciúma, Brazil, 2003.

[32] L. M. Pierrot and C. Schlindwein, "Variation in daily flight activity and foraging patterns in colonies of uruçu-Melipona scutellaris Latreille (Apidae, Meliponini)," Revista Brasileira de Zoologia, vol. 20, no. 4, pp. 565-571, 2003.

[33] F. B. Borges and B. Blochtein, "Atividades externas de Melipona marginata obscurior Moure (Hymenoptera, Apidae), em distintas épocas do ano, em São Francisco de Paula, Rio Grande do Sul, Brasil," Revista Brasileira de Zoologia, vol. 22, no. 3, pp. 680-686, 2005.

[34] B. A. Souza, C. A.L. Carvalho, and R. M.O. Alves, "Flight activity of Melipona asilvai moure (Hymenoptera: Apidae)," Brazilian Journal of Biology, vol. 66, no. 2B, pp. 731-737, 2006.

[35] B. Heinrich, The Hot-Blooded Insects: Strategies and Mechanisms of Thermoregulation, Spring, Berlin, Germany, 1993.

[36] S. D. Leonhardt, K. Dworschak, T. Eltz, and N. Blüthgen, "Foraging loads of stingless bees and utilization of stored nectar for pollen harvesting," Apidologie, vol. 38, pp. 125-135, 2007.

[37] N. W. Calderone and B. R. Johnson, "The within-nest behaviour of honeybee pollen foragers in colonies with a high or low need for pollen," Animal Behaviour, vol. 63, no. 4, pp. 749-758, 2002.

[38] K. Crailsheim, N. Hrassnigg, R. Gmeinbauer, M. J. Szolderits, L. H. W. Schneider, and U. Brosch, "Pollen utilization in nonbreeding honeybees in winter," Journal of Insect Physiology, vol. 39, no. 5, pp. 369-373, 1993.

[39] N. Hrassnigg and K. Crailsheim, "The influence of brood on the pollen consumption of worker bees (Apis mellifera L.)," Journal of Insect Physiology, vol. 44, no. 5-6, pp. 393-404, 1998.

[40] A. Kleinert-Giovannini and V. L. Imperatriz-Fonseca, "Flight activity and responses to climatic conditions of two subspecies of Melipona marginata Lepeletier (Apidae, Meliponinae)," Journal of Apicultural Research, vol. 25, no. 1, pp. 3-8, 1986.

[41] S. Iwama, "A influência dos fatores climáticos na atividade externa de Tetragonisca angustula (Apidae, Meliponinae)," Boletim do Museu de Zoologia da Universidade de São Paulo, vol. 2, pp. 189-201, 1977.

[42] L. R. Bego, "On some aspects of bionomics in Melipona bicolor bicolor Lepeletier (Hymenoptera, Apidae, Meliponinae)," Revista Brasileira de Entomologia, vol. 27, no. 3-4, pp. 211-224, 1983.

[43] D. Simões, Estudos sobre a regulação social em Nannotrigona (Scaptotrigona) postica Latreille, com especial referência a aspectos comportamentais (Hymenoptera, Apidae, Meliponinae), dissertation, University of São Paulo, Ribeirão Preto, Brazil, 1974.

[44] C. Camillo-Atique, Estudo da variabilidade etológica de Friesella incluindo a caracterização de espécies crípticas (Hym. Meliponinae), thesis, University of São Paulo, Ribeirão Preto, Brazil, 1977.

[45] K. M. Giannini, "Labor division in Melipona compressipes fasciculate Smith (Hymenoptera: Apidae: Meliponinae)," Anais da Sociedade Entomológica do Brasil, vol. 26, no. 1, pp. 153$162,1997$.

[46] S. Bellusci and M. D. Marques, "Circadian activity rhythm of the foragers of a eusocial bee (Scaptotrigona aff depilis, Hymenoptera, Apidae, Meliponinae) outside the nest," Biological Rhythm Research, vol. 32, no. 2, pp. 117-124, 2001. 
[47] H. G. Spangler, "Daily activity rhythms of individual worker and drone honey bees," Annals of the Entomological Society of America, vol. 65, no. 5, pp. 1073-1076, 1972.

[48] A. G. Hart and F. L.W. Ratnieks, "Task-partitioned nectar transfer in stingless bees: work organisation in a phylogenetic context," Ecological Entomology, vol. 27, no. 2, pp. 163-168, 2002. 

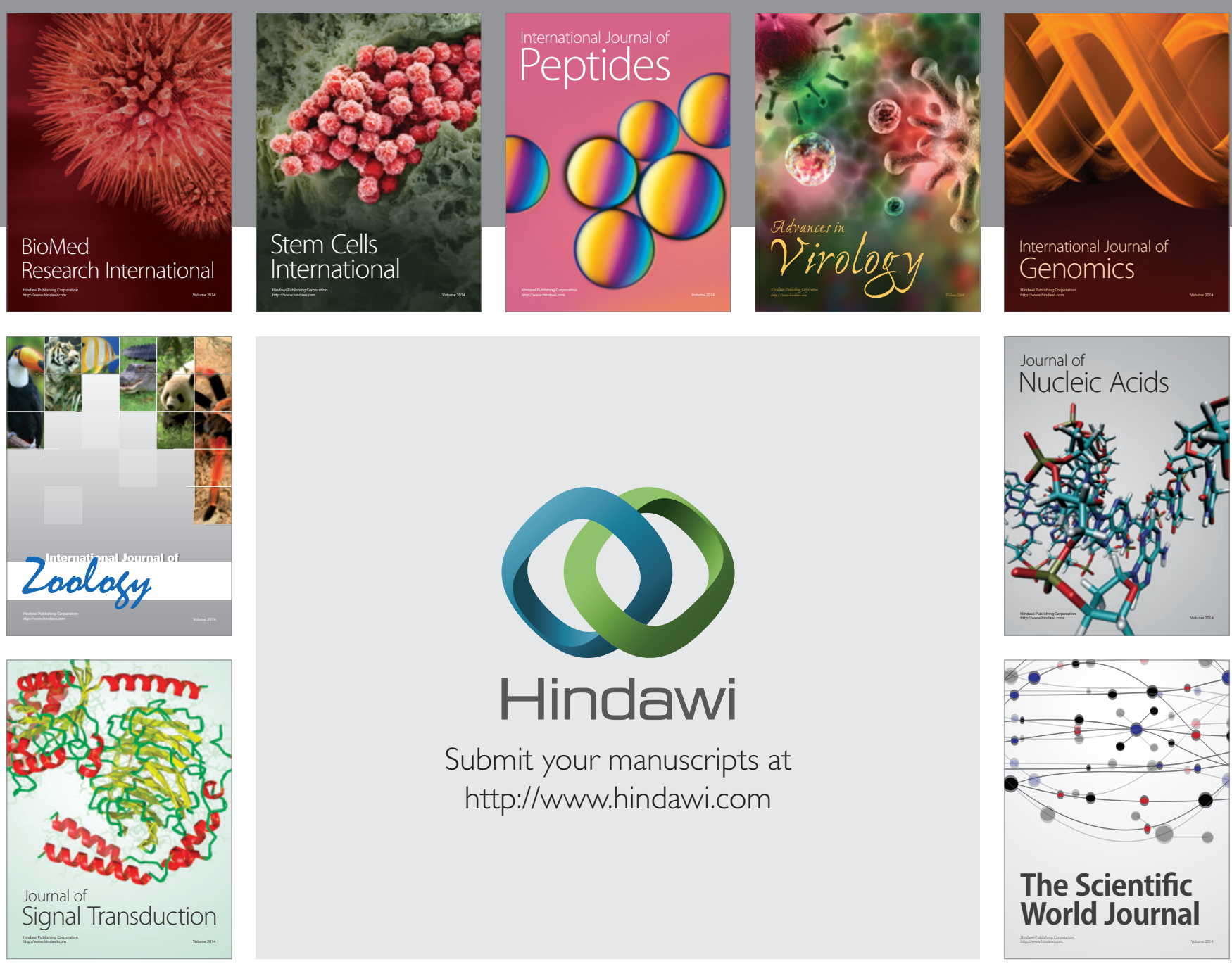

Submit your manuscripts at

http://www.hindawi.com
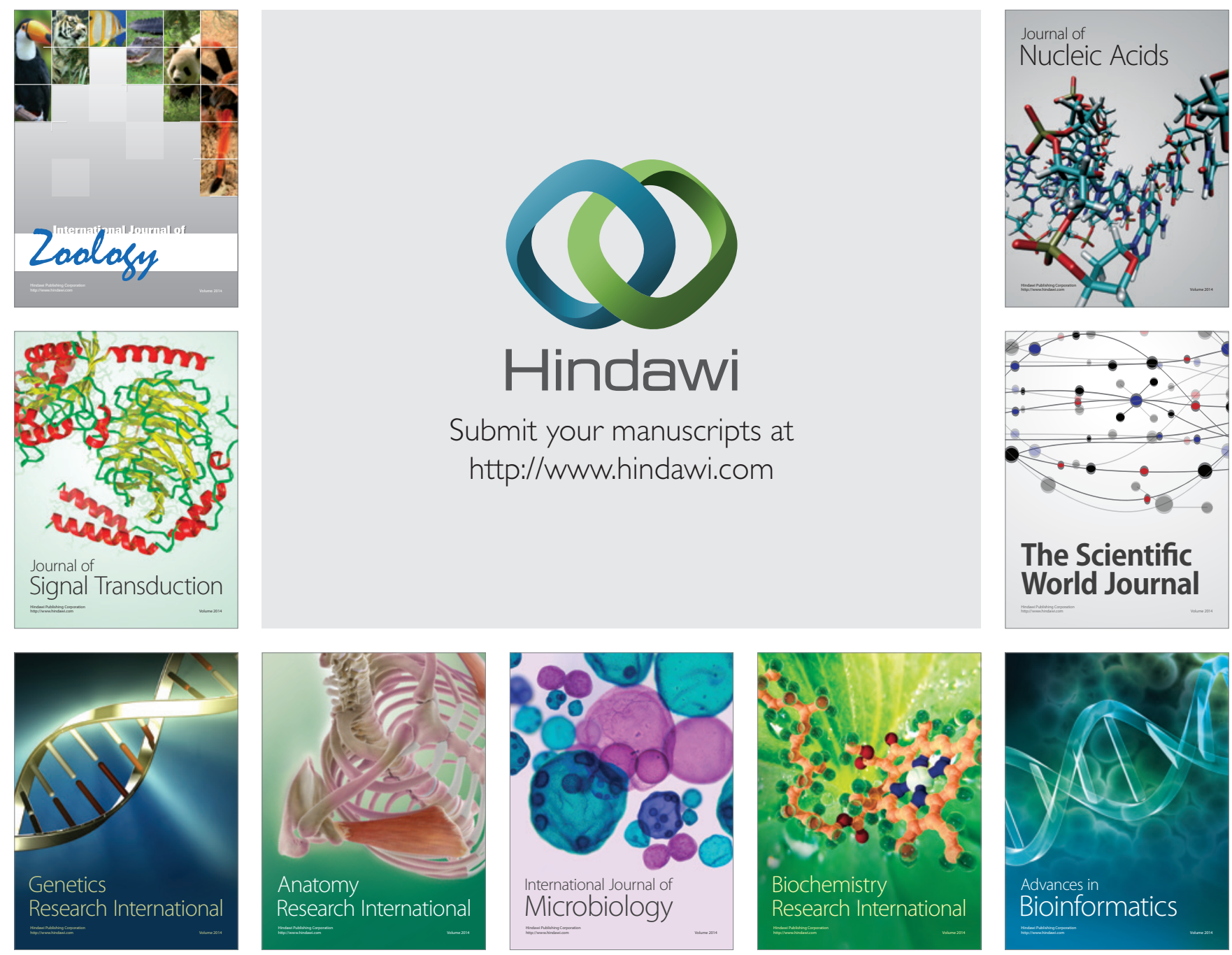

The Scientific World Journal
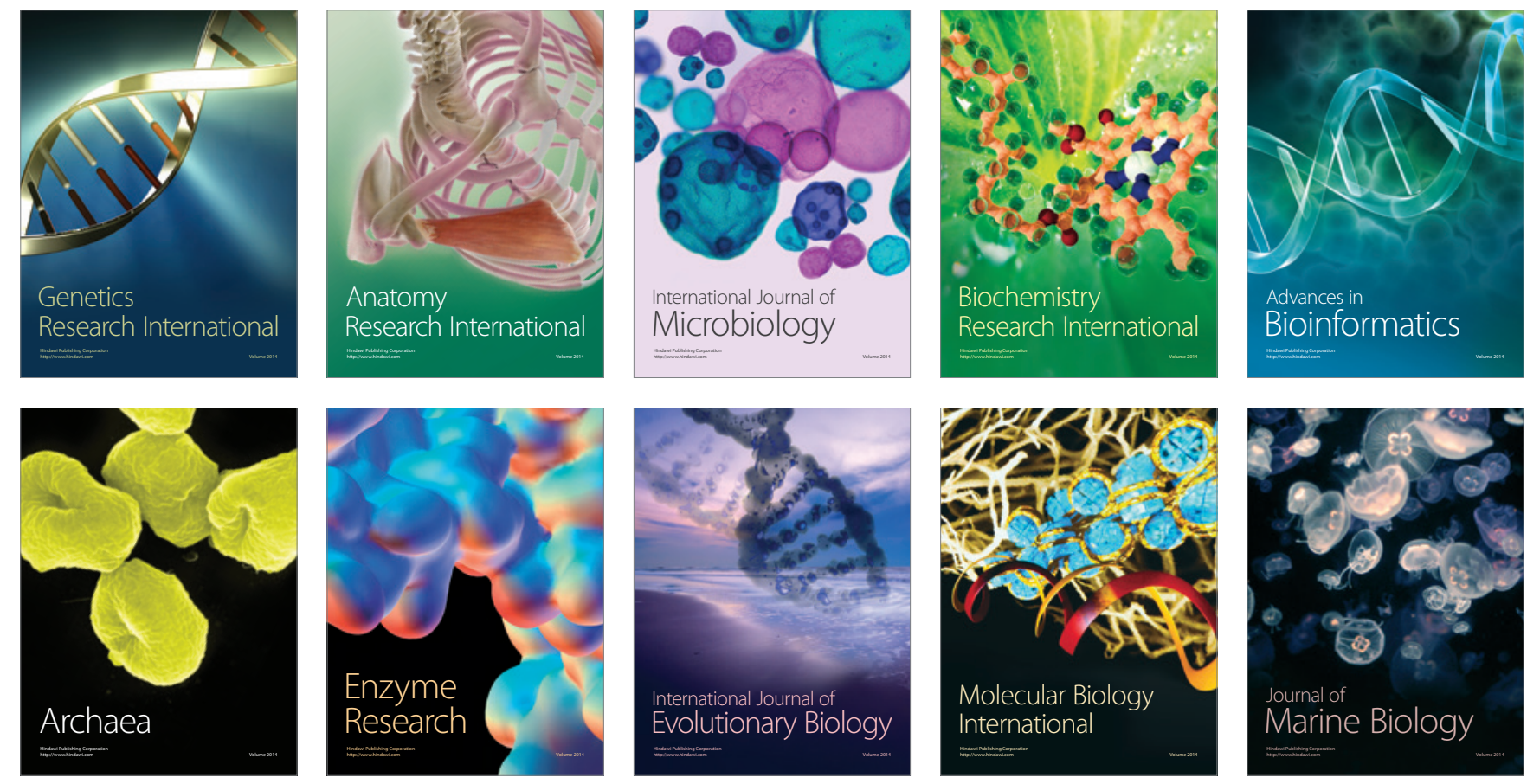